\title{
Democracy and International Investment Law
}

\author{
LORENZO COTULA*
}

\begin{abstract}
The expanding reach of international investment law and the negotiation of major economic treaties between democratic polities have prompted new debates about the relationship between democracy and the international investment regime. This article develops an analytical framework for understanding that relationship. It first unpacks the concept of democracy, exploring the 'rules-based' and 'action-based' conceptions that emerge from political theory and their relevance to international investment law. It then examines three themes that frame the relationship between democracy and international investment law: the interface between the investment regime and national democratic space; the place of democratic processes in investment treaty making; and public participation in the settlement of investment disputes. The interplay between rules- and action-based dimensions provides a common thread across the three themes. The article concludes that there is a gap between formal rules and citizen action in promoting democratic oversight, and significant scope to develop more effective mechanisms to install democratic governance in the creation and implementation of international investment law.
\end{abstract}

\section{Keywords}

constitutional law; democracy; investment treaties; investor-state arbitration; parliament

\section{FRAMING THE ISSUE}

The relationship between law and politics has long framed evolutions in international investment law. The emergence of the modern international investment regime was accompanied by debates about the perceived need to 'depoliticize', and correspondingly to 'juridify', investment disputes. In this context, international investment treaties and arbitration were seen as tools to replace the politics of diplomatic protection with expert legal solutions developed through impartial international adjudication. ${ }^{\mathrm{I}}$ The critical literature has challenged these narratives, emphasizing the continued pervasiveness of politics in the international

\footnotetext{
* $\quad$ Principal Researcher in Law and Sustainable Development, International Institute for Environment and Development (IIED); and Visiting Research Fellow, Centre for the Law, Regulation and Governance of the Global Economy (GLOBE), Warwick Law School [lorenzo.cotula@iied.org].

I I.F.I. Shihata, 'The Settlement of Disputes Regarding Foreign Investment: The Role of the World Bank, with Particular Reference to ICSID and MIGA', (I986) I(I) American University International Law Review 97, at I03.
} 
investment regime, ${ }^{2}$ and in international law more broadly. ${ }^{3}$ While the extent and precise contours of that pervasiveness are contested, there is little doubt that politics remain an important parameter in the development of international investment law. Choices on whether to conclude an international investment treaty, and in what form, are eminently political: investment treaties 'are agreements rooted in a certain worldview, which vindicate certain internal socio-economic interests', ${ }^{4}$ and which can have important distributive consequences. ${ }^{5}$ Different governments and interest groups can legitimately have diverse positions on how to mediate the ensuing tradeoffs, outlining horizons beyond which technical analyses give ground to political considerations. Investment disputes can also involve political dimensions, particularly where politically sensitive assets are at stake, and several arbitral tribunals have dealt with arguments that politics unduly influenced a government's handling of investment issues. ${ }^{6}$ The enduring relevance of politics to the investment regime raises fundamental questions about how political choices are made, and about the place of democratic governance in international investment law.

These questions form part of wider, longstanding debates about the relationship between democracy and international law in general. As the First World War raged, international jurist Elihu Root elaborated on the Kantian ideal of 'perpetual peace' and argued that the rise of democracy would make war less likely and observance of international law a higher priority. ${ }^{7}$ The end of the Cold War triggered new debates about the role of international law in promoting democracy, including through the articulation of a proposed right to democratic governance. ${ }^{8}$ The growing interdependence among states increasingly calls for international solutions to global problems, ${ }^{9}$ adding new dimensions to debates traditionally focused on national governance in the context of the 'Westphalian' state: the expanding reach of international law challenges democratic polities to install oversight mechanisms in the making and implementation of international law itself. ${ }^{\text {Io }}$

The recent or ongoing negotiation of major trade and investment treaties has added new momentum to these debates. Heated discussions have accompanied

D. Schneiderman, Resisting Economic Globalization: Critical Theory and International Investment Law (2013), 2.

See generally M. Koskenniemi, 'The Fate of Public International Law: Between Technique and Politics', (2007) 70(I) Modern Law Review I-30.

4 J.H.H. Weiler, 'The Geology of International Law - Governance, Democracy and Legitimacy', (2004) 64 Zeitschrift für Ausländisches öffentliches Recht und Völkerrecht 547, at 556 (writing about international economic treaties more generally).

5 J. Bonnitcha, Substantive Protection under Investment Treaties: A Legal and Economic Analysis (2014), 83-IO2; Schneiderman, supra note 2 , at 2.

6 See, e.g., Compañía de Aguas del Aconquija SA and Vivendi Universal SA v. Republic of Argentina (Award, 2007) ICSID Case No. ARB/97/3 (Vivendi II), at 7.4.I 8-7.4.46, 7.5.8; Biwater Gauff(Tanzania) Limited v. United Republic of Tanzania (Award, 2008) ICSID Case No. ARB/05/22, at 497-500, 519; Abengoa S.A. y COFIDES S.A. v. Estados Unidos Mexicanos (Award, 2013) ICSID Case No. ARB(AF)/og/2, at I 92-297, 572-610.

7 E. Root, 'The Effect of Democracy on International Law', (I9I7) II Proceedings of the American Society of International Law 2-I I.

8 T.M. Franck, 'The Emerging Right to Democratic Governance', (I992) 86(I) American Journal of International Law 46-9r. For a sceptical view, see J. Crawford, 'Democracy and the Body of International Law', in G.H. Fox and B.R. Roth (eds.), Democratic Governance and International Law (2000), 91, at 95-6.

9 A. de Mestral and E. Fox-Decent, 'Rethinking the Relationship between International and Domestic Law', (2008) 53 McGill Law Journal 573, at 575.

Io Weiler, supra note 4 , at $56 \mathrm{I}$. 
the negotiation of the proposed Comprehensive Economic and Trade Agreement (CETA) between the EU and Canada, ${ }^{\text {II }}$ the proposed Trans-Pacific Partnership (TPP) among I 2 countries around the Pacific, ${ }^{\text {I2 }}$ and the proposed Transatlantic Trade and Investment Partnership (TTIP) between the EU and the US. ${ }^{13}$ Given the far-reaching repercussions such treaties could have in a wide range of policy areas, questions are being asked as to whether even 'mature' democracies provide adequate channels for public oversight of the treaties - and some scholars have called for strengthening the parameters of democratic governance in international economic diplomacy. ${ }^{\text {I4 }}$ Investment chapters and standalone investment treaties that allow businesses to initiate arbitrations against states over measures taken by elected governments or parliaments have attracted particularly vigorous debates, and raised public concerns that international regulation might unduly restrict space for democratic governance. $^{\text {I5 }}$

The complexities are also becoming increasingly clear. Contemporary economic treaties typically involve difficult technical issues. So any discussion about legal arrangements for democratic oversight also requires exploring ways to ensure that oversight is properly informed, and considering institutional vehicles that can most appropriately facilitate citizen engagement. At a more conceptual level, there have been concerns that ill-thought through attempts to bridge democratic governance and the investment regime might provide new avenues for cultural imperialism; these concerns are particularly relevant to suggestions that investor-state arbitration is problematic when applied to some polities but not others, with parallels being drawn between today's notion of 'democratic' polities and the now discredited concept of 'civilized' nations. ${ }^{16}$ Among other things, these concerns call for a more fine-grained understanding of democracy in its multiple shapes and cultural roots, ${ }^{17}$ including beyond Western traditions. ${ }^{18}$ Additional conceptual challenges are at play, because the notion of democracy presupposes an identifiable people (demos) and has been associated in modern history with the emergence of the nation state. Rising to

II 2016 EU-Canada Comprehensive Economic and Trade Agreement, Interinstitutional File 2016/0206 (NLE) I0973/I6 (I4 September 20I6). Adopted in Brussels on 30 October 20I6; not in force.

I2 Trans-Pacific Partnership, available at ustr.gov/trade-agreements/free-trade-agreements/trans-pacificpartnership/tpp-full-text. Signed in Auckland on 4 February 20I6; not in force.

I3 In the EU, a public petition on CETA and TTIP reportedly marshalled over 3 million signatures. See L. Williams, 'TTIP: Three Million People Sign Petition to Scrap Controversial Trade Deal', The Independent, 5 October 2015, available at www.independent.co.uk/news/business/ttip-threemillion-people-sign-petition-to-scrap-controversial-trade-deal-a66804I I.html.

I4 'Namur Declaration', 5 December 20I6, available at media.wix.com/ugd/2efde 4 9e3b80497df24b79a8007e7309177c6d.pdf. See also 'Trading Together: For Strong and Democratically Legitimized EU Investment Agreements', 25 January 2017, available at www.trading-together-declaration.org/; E.U. Petersmann, 'Transformative Transatlantic Free Trade Agreements without Rights and Remedies of Citizens?', (2015) I 8 Journal of International Economic Law 579-607.

I5 See, e.g., M. Robinson, 'Is Democracy Threatened if Companies Can Sue Countries?', BBC, 3I March 20I5, available at www.bbc.co.uk/news/business-32 I 16587.

I6 See A. Kulick, 'Investment Arbitration, Investment Treaty Interpretation, and Democracy', (20I5) 4(2) Cambridge Journal of International and Comparative Law 44I-60.

17 For example, UN General Assembly Res. 55/96 recognizes 'the rich and diverse nature of the community of the world's democracies, which arise out of all of the world's social, cultural and religious beliefs and traditions'. UNGA Res. 55/96 Promoting and Consolidating Democracy, UN Doc. A/RES/55/96 (200I), at preambular para. 7 .

I8 See A. Sen, The Idea of Justice (2009), 322-3, 329-35. 
the challenge might therefore involve rethinking not only how international law is made and implemented, but also 'the very building blocks of democracy'. ${ }^{\text {9 }}$

This article explores the relationship between democracy and international investment law. Given the vast field of inquiry, the article primarily develops and tests an analytical framework. As more evidence comes to light, this framework could be validated or revisited, and in any case further developed. While this theme is now at the centre of lively debates in particular geographies, including the EU, the article takes an international perspective. The article first unpacks the concept of democracy, exploring the 'rules-based' and 'action-based' conceptions that emerge from political theory and their relevance to international investment law. It then explores three themes that frame the relationship between democracy and international investment law: the interface between the investment regime and national democratic space; the place of democratic processes in investment treaty making; and public participation in the settlement of investment disputes. The interplay between rules- and action-based dimensions of democracy provides a common thread across the three themes. The article argues that there is a gap between formal rules and citizen action in promoting democratic oversight, and significant scope for more effective legal arrangements to install democratic governance in the making and implementation of international investment law.

\section{UNPACKING DEMOCRACY: BETWEEN RULES AND ACTION}

Several strands of scholarly writing in political theory, philosophy, law, history and sociology - to mention but a few relevant academic disciplines - have enriched public understanding of democratic governance. It is impossible to do justice to this vast body of thought in the limited space available here. In general terms, democracy refers to the diverse arrangements for configuring political authority that enable, in Abraham Lincoln's celebrated words, 'government of the people, by the people, for the people'. ${ }^{20}$ Beyond this broad formulation, positions diverge widely on desirable or actually observed arrangements to ensure government 'by the people', partly reflecting different political alignments. In political theory, some conceptions focus on the features and benefits of representative democracy, ${ }^{2 \mathrm{I}}$ and on electoral mechanisms for selecting those in power; ${ }^{22}$ while other conceptions emphasize the value of direct, grassroots-level deliberation. ${ }^{23}$ Recognizing the dark side of unfettered majority rule, many theorists have advanced conceptions of liberal democracy that combine government 'by the people' with safeguards for human rights and the rule

i9 Weiler, supra note 4, at 56r.

20 A. Lincoln, 'Address Delivered at the Dedication of the Cemetery at Gettysburg', I 9 November I 863, available at www.abrahamlincolnonline.org/lincoln/speeches/gettysburg.htm.

2 I J.S. Mill, Considerations on Representative Government (I86I).

22 J. Schumpeter, Capitalism, Socialism, and Democracy (I972). See also the emphasis on electoral competition in the public choice school, e.g., J.M. Buchanan and G. Tullock, The Calculus of Consent: Logical Foundations of Constitutional Democracy (1962).

23 See, e.g., J. Habermas, Between Facts and Norms: Contributions to a Discourse Theory of Law and Democracy (translated by W. Rehg) (I 996); J. Rawls, 'The Idea of Public Reason Revisited', (I997) 64(3) University ofChicago Law Review 765-807; Sen, supra note I 8, at 324-5. 
of law. ${ }^{24}$ Sensible ways to cluster and classify the diverse conceptions of democracy are almost endless, depending on the nature and purpose of the analysis. One useful approach distinguishes conceptions based on the relative importance they attach to rules and to action in framing democratic processes. ${ }^{25}$

Some conceptions of democracy focus on the formal rules and procedures for public decision-making. While the specific features of these rules and procedures vary, the focus is often on electoral processes and relations of democratic accountability. ${ }^{26}$ In this context, formal belonging to a polity is the defining feature of citizenship, which entails a set of legal rights and liberties shaping the ability of citizens to participate in the management of public affairs. Public institutions are the official guarantors of these rights and liberties, and ultimately of democratic governance itself. ${ }^{27}$ While different terms have been used to describe these ways of framing democratic governance, this article refers to them as the rules-based conceptions of democracy. In relation to international investment law, relevant aspects would include, for example, the legal right of citizens to elect parliamentarians and the formal processes that define the ability of parliament to influence treaty making. Depending on the jurisdiction, referenda enabling citizens to vote on the ratification of treaties might also be relevant, while formal procedures for public participation in investor-state arbitration would extend democratic safeguards to international adjudication.

A second set of conceptions focuses on the practices of 'contestation and negotiation' whereby citizens seek to influence the management of public affairs. ${ }^{28}$ These approaches conceptualize democracy not as a state of affairs defined by formal rules and procedures, but as a never achieved, always evolving practice centred on debate, dissent and deliberation. ${ }^{29}$ Relevant strands of thought include deliberative democracy theories that highlight the role of rational, collaborative deliberation; ${ }^{30}$ conceptions of democracy that consider dissent and contestation as the defining features of democratic politics; ${ }^{3 \mathrm{I}}$ and analyzes that point to the importance of civic associations and grassroots co-operation in establishing the cultural preconditions for democracy to prosper. ${ }^{32}$ This framing of democracy around the practices of citizen engagement is not restricted to those who have formal citizenship status. Rather, it is the practice of engaging that constitutes the citizen. ${ }^{33}$ And in the context

24 See, e.g., R. Dworkin, Taking Rights Seriously (1977), 223-47; R. Dahl, On Democracy (2000); Habermas, supra note 23 .

25 This classification is inspired by J. Tully, 'On Modern and Diverse Citizenship', in J. Tully (ed.), On Global Citizenship: James Tully in Dialogue (2014), 3-100 (using different terminology).

26 See, e.g., Dahl's fundamental criteria for procedural democracy. Dahl, supra note 24.

27 Tully, supra note 25 , at I4-I5.

28 Tully, supra note 25 , at 36.

29 J. Gaventa, 'Triumph, Deficit or Contestation? Deepening the "Deepening Democracy” Debate', (2006) Institute of Development Studies Working Paper 264.

30 Habermas, supra note 23; Sen, supra note I8, at 324-5. While escaping political philosophy labels, Hannah Arendt saw 'acting together' through inter-relational 'word and deed' as the distinctive feature of human life. H. Arendt, The Human Condition (I958), at I76, I88, I90, I98, 200, 203.

3I J. Rancière, 'Introducing Disagreement', (2004) 9(3) Algelaki: Journal of the Theoretical Humanities 3-9.

32 A. de Tocqueville, La Démocratie en Amérique, Vol. I (I835); R.D. Putnam, Bowling Alone: The Collapse and Revival of American Community (2000).

33 Tully, supra note 25 , at $37-8$. 
of complex technical issues, vested interests, and power imbalances, citizen action involves not just the abstract, individual citoyen of the I789 French Declaration of the Rights of Man and the Citizen, but the practices of deliberation, participation, and contestation by citizens in their collective and organized capacity. At the same time, questions have been raised about the legitimacy of organized groups such as non-governmental organizations (NGOs) to represent public concerns. ${ }^{34}$ With regard to international investment law, these 'action-based' conceptions of democracy are reflected, for example, in the advocacy carried out by NGOs and social movements such as trade unions and consumer groups in the context of economic treaty negotiations, and proactive engagement of and with parliament in treaty-making processes. They are also reflected in debates about whether the international investment regime can unduly affect space for citizens to influence public decisions where meeting citizens' demands would undermine business interests. ${ }^{35}$

Both rules- and action-based conceptions of democracy have formed the object of critique. Some scholars have applied insights from the work of Michel Foucault to show that, even in a perfect procedural democracy, the operation of power in the production of knowledge, interests, and identities can hollow out democratic values without formally contradicting democratic procedures. ${ }^{36}$ And while deliberative democracy has received widespread support from both theorists and practitioners, it has also come under scrutiny - for example, on the ground that socio-economic inequalities can influence concrete patterns of deliberative democracy, ${ }^{37}$ or that deliberative democracy theories emphasize 'elitist' features such as reason, expertise, and constructive dialogue and underestimate the role of mass mobilization and countervailing power. ${ }^{38}$

Rules- and action-based conceptions of democracy differ in philosophical terms, and ultimately in their practical implications; but they are not mutually exclusive. In important respects, the two conceptions reflect complementary dimensions of the democratic process. For example, savvy use of legal rights and processes can support citizen strategies of negotiation and contestation - including through the exercise of the 'political' rights of freedom of expression, assembly, and association, and through the strategic use of freedom of information legislation, judicial review, or public interest litigation. On the other hand, the reality of authoritarian regimes operating under formally democratic constitutions highlights the imperative for even rules-based conceptions to explore how the rules are applied. The coexistence of rules- and action-based dimensions in concrete manifestations of democratic governance is illustrated particularly clearly by pioneering initiatives

34 See, e.g., S. Charnovitz, 'Nongovernmental Organizations and International Law', (2006) Ioo(2) American Journal of International Law 348, at 363-8.

35 See, e.g., D. Schneiderman, 'Investing in Democracy? Political Process and International Investment Law', (2010) 60(4) University of Toronto Law Journal 909, at 910.

36 N. Gordon, 'Dahl's Procedural Democracy: A Foucauldian Critique', (200I) 8(4) Democratization $23-40$.

37 For example, several studies have assessed India's local government system. See, e.g., S.M. Rai, 'Deliberative Democracy and the Politics of Redistribution: The Case of the Indian Panchayats', (2007) 22(4) Hypatia 64-80; R. Ban, S. Jha and V. Rao, 'Who Has Voice in a Deliberative Democracy? Evidence from Transcripts of Village Parliaments in South India', (2012) 99(2) Journal of Development Economics 428-38.

38 For a discussion, see L.M. Sanders, 'Against Deliberation', (I 997) 25(3) Political Theory 347-76. 
to institutionalize the practices of deliberative democracy within the machinery of government, for instance through arrangements for participatory budgeting and 'account giving'. ${ }^{39}$ While legal training might make lawyers instinctively inclined to address rules-based aspects, considering action-based dimensions as well is essential to develop a more realistic account of how democracy and international investment law intersect.

As the system of legal rules governing relations among states, and in some respects between states and private actors, international law would at first sight seem to inherently favour rules-based conceptions of democracy. Human rights treaties such as the International Covenant on Civil and Political Rights (ICCPR) affirm fundamental rights that establish formal vehicles for citizen engagement - including the right of citizens to vote and, in addition, 'to take part in the conduct of public affairs, directly or through freely chosen representatives'. ${ }^{40}$ The Human Rights Committee, which oversees the implementation of the ICCPR, has clarified that this right covers the formulation and implementation of policy at both national and international levels. ${ }^{4 \text { I }}$ While most human rights pertain to all human beings, the rights to vote and to take part in the conduct of public affairs are restricted to those holding formal citizenship, ${ }^{42}$ thereby cementing a rules-based perspective that emphasizes the formal legal status of citizens in the democratic process. Giving effect to the principle that '[e]nvironmental issues are best handled with participation of all concerned citizens, at the relevant level', ${ }^{43}$ international environmental law also establishes 'procedural rights' that strongly resonate with rules-based conceptions of democracy - namely, access to information, public participation in decision-making, and access to justice. ${ }^{44}$

However, international law also corroborates the relevance of action-based conceptions. The Human Rights Committee has clarified that, in addition to voting rights, citizens can take part in public affairs in other ways, including 'by exerting influence through public debate and dialogue with their representatives or through

39 Gaventa, supra note 29, at I5-I7. Besides Brazil's oft cited experience with participatory budgeting in Porto Alegre, B. De Sousa Santos, 'Two Democracies, Two Legalities: Participatory Budgeting in Porto Alegre, Brazil', in B. De Sousa Santos and C.A. Rodríguez-Garavito (eds.), Law and Globalization from Below: Towards a Cosmopolitan Legality (2005), 310-38, see also initiatives to institutionalize citizen participation at local government level in West Africa, B. Guèye, Le Budget Participatif en Pratique (2008), available at www.iedafrique.org/IMG/pdf/budget_participatif_en_pratique.pdf.

40 Art. 25, I 966 International Covenant on Civil and Political Rights, 6 ILM 368 (I967). See also Art. 2I of the Universal Declaration of Human Rights, UNGA Res. 2 I7A (III), UN Doc. A/8Io (I948), at 7 I. For an example from a regional human rights treaty, see Art. 23, I969 American Convention on Human Rights, 9 ILM 99 (I969) (ACHR).

4I UN Human Rights Committee, General Comment No. 25: The Right to Participate in Public Affairs, Voting Rights and the Right of Equal Access to Public Service, I2 July I996, UN Doc. CCPR/C/2 I/Rev.r/Add.7 (I996), at 5 .

42 ICCPR, supra note 40, Art. 25. ACHR, supra note 40, Art. 23. See also General Comment No. 25, supra note 4I, at 3 .

43 Rio Declaration on Environment and Development, UN Doc. A/CONF.I5I/26 (I992), Principle Io, available at www.un.org/documents/ga/confi5 I/aconfi5I 26-Iannexi.htm.

44 I 998 Convention on Access to Information, Public Participation in Decision-Making and Access to Justice in Environmental Matters, 38 ILM 5I 7 ( 1999) (Aarhus Convention), Arts. 4, 6 and 9. The Aarhus Convention has limited geographic scope, covering Europe and the former Soviet Union, but a comparable regional treaty is being developed in Latin America and the Caribbean. For more information on this process, see the UN Economic Commission for Latin America and the Caribbean, available at www.cepal.org/en/principio-Io. 
their capacity to organize themselves'. ${ }^{45}$ Important political rights, such as freedom of expression, assembly, and association, are not restricted to those holding formal citizenship status. These circumstances create space for action-based notions of citizenship, whereby agents become citizens 'in virtue of actual participation in civic activities' ${ }^{46}$ The United Nations Human Rights Council too has stressed the importance of action-based dimensions, emphasizing the role of political opposition, civil society, the media, human rights defenders, and citizens themselves in ensuring that advances are made. ${ }^{47}$ Because of these conceptual and jurisprudential considerations, there is a strong case for examining the relationship between democracy and international investment law through the prism of both rules- and action-based dimensions.

\section{INTERNATIONAL INVESTMENT LAW AND NATIONAL DEMOCRATIC SPACE}

A good place to start exploring how democracy and the investment regime intersect concerns the relationship between international investment law and space for democratic decision-making at national and subnational levels. The international investment regime establishes legal safeguards to protect foreign investment against the exercise of public powers - even if public action responds to democratic decisionmaking. This framing locates international investment law at the interface between liberal safeguards and democratic governance. While the framing involves multiple dimensions, two aspects provide particularly fertile ground for exploration: first, the notion that foreign investors need international protection because they are excluded from the national democratic process; and second, the much-debated question of whether the international protection of foreign investment unduly restricts national democratic space. The next two sections examine each issue in turn, covering both rules- and action-based dimensions.

\section{3.r. Citizenship and the foundations of international investment law}

The first issue concerns the normative justification for the special legal safeguards that international investment law provides to foreign investors and investments, over and above the protections that may be available under national law. One line of argument justifies these international safeguards on the ground that foreign investors, as non-nationals, lack formal rights of political representation in the country in which they operate. ${ }^{48}$ This lack of political rights would deprive foreign investors of any voice in decision-making, and make them vulnerable to

\footnotetext{
General Comment No. 25, supra note 4I, at 8.

Tully, supra note 25 , at 37 .

UN Human Rights Council Res. I9/36 Human Rights, Democracy and the Rule of Law, UN Doc. A/HRC/RES/I9/36 (2012), at 3, 6-7.

48 See Técnicas Medioambientales Tecmed SA v. The United Mexican States (Award, 2003) ICSID Case No. ARB(AF)/oo/2, at I 22; Joseph Charles Lemire v. Ukraine (Award, 20 I I) ICSID Case No. ARB/06/I 8, at 57. See also James v. United Kingdom, Judgment of 2 I February I986, [1986] ECHR 2 (Ser. A, No. 98), para. 63.
} 
political manipulation and scapegoating. ${ }^{49}$ Some commentators have compared investment treaties to the constitutional safeguards that, in conceptions of liberal democracy, aim to minimize the risk of a 'tyranny of the majority' - namely, through the entrenchment of rights that even majority vote cannot overturn. ${ }^{50}$ This argument shifts the emphasis from popular sovereignty to the safeguards of liberal democracy, and in a constitutional law context it can affect the distribution of power between the legislature, which makes law, and the judiciary, which in many jurisdictions has the power to determine whether legislation complies with the constitution. ${ }^{\text {I }}$

At first sight, there are parallels between the safeguards established by national constitutions and those provided by international investment law. Like the bills of rights entrenched in many national constitutions, investment treaties set standards of governance against which the conduct of public authorities can be reviewed. And like constitutions, investment treaties establish safeguards aimed at surviving electoral cycles: termination clauses typically prevent unilateral treaty termination for specified periods of time (often ten or I5 years) and provide that the treaty continues to apply to investments made before termination (often for another ten or I5 years); ${ }^{2}$ while renegotiating treaties it requires the agreement of the other states parties. However, there are complex legal and theoretical questions about the appropriateness of this comparison: unlike bills of rights, investment treaties tend not to use the language of 'rights', they create reciprocal obligations between states. Further, national constitutions and international treaties operate at different levels, and in different ways, with significant practical implications. Depending on the jurisdiction, for example, a constitutional court may have the power to strike down norms it deems unconstitutional - a power international investor-state arbitral tribunals lack. On the other hand, international investment law may allow investors to claim damages in circumstances where national law provides no remedy, in deference to parliamentary sovereignty. ${ }^{53}$ From a political perspective, constitutions - at least in theory - embody the social contract, and their drafting or modification is (or should be) carried out through mechanisms that, 'guarantee extraordinarily high levels of democratic consent'. ${ }^{44}$ As will be seen, there are real doubts as to whether

49 T. Wälde, 'Renegotiating Acquired Rights in the Oil and Gas industries: Industry and Political Cycles Meet the Rule of Law', (2008) I(I) Journal of World Energy Law \& Business 55, at 63-5.

50 For diverse perspectives on this point, see, e.g., D. Schneiderman, Constitutionalizing Economic Globalization: Investment Rules and Democracy's Promise (2008), 4, 9-10, 37-45; S. Montt, State Liability in Investment Treaty Arbitration: Global Constitutional and Administrative Law in the BIT Generation(2009), I 2-I6. See also S.D. Myers, Inc. v. The Government of Canada (Partial Award, I2 November 2000, Separate Opinion of Bryan Schwartz), UNCITRAL, NAFTA Ch. I I, para. 34.

5I M. Schwartzberg, Democracy and Legal Change (2007), I 99.

52 J. Pohl, 'Temporal Validity of International Investment Agreements: A Large Sample Survey of Treaty Provisions', (2014) OECD Working Paper on International Investment 2013/04, available at www.oecd.org/investment/investment-policy/WP-20I3_4.pdf.

53 A. De Mestral and R. Morgan, 'Does Canadian Law Provide Remedies Equivalent to NAFTA Chapter II Arbitration?', (2016) Centre for International Governance Innovation Investor-State Arbitration Series Paper No. 4 .

54 J. Kurtz, 'Building Legitimacy through Interpretation in Investor-State Arbitration: On Consistency, Coherence, and the Identification of Applicable Law', in Z. Douglas, J. Pauwelyn and J.E. Viñuales (eds.), The Foundations of International Investment Law: Bringing Theory into Practice (2014), 257, at 263. 
comparable levels of democratic deliberation have accompanied investment treaty making.

More fundamentally, arguments about the political marginalization of foreign investors deserve closer scrutiny. First, neither foreign nor domestically incorporated companies have the right to vote, so there is no discrimination in this respect; 55 though foreign investors can be individuals too, and individuals brought several investor-state arbitration claims. ${ }^{56}$ Second, those arguments embody a rules-based view of political influence that does not reflect the multiple real-world channels that businesses can use to affect policy, including high-level political access and diverse lobbying strategies. ${ }^{57}$ In other words, foreign investors are excluded from rules-based citizenship, but they may still be able to significantly influence decision-making. Also, arguments about the political marginalization of foreign investors imply a localized and insulated view of politics that does not consider the effects of globalization on the bounds of possible public action, and they ignore the fact that in authoritarian contexts citizens may also face constrained political space. Further questions arise where political economy factors and practical constraints such as poverty and illiteracy disenfranchize groups of citizens in spite of their political rights and even affirmative action measures, particularly in low- and middle-income countries. ${ }^{5}$ Once the attention shifts away from a purely rules-based conception of democracy, and once account is taken of (constraints affecting) action-based dimensions, it becomes apparent that social, political, and economic factors can undermine the ability of citizens to deliberate and influence, and even place them at a disadvantage vis-à-vis foreign (or domestic) businesses. These considerations cast real doubt over conventional arguments that point to foreign investors' lack of formalized political rights as the normative justification for international investment protection. ${ }^{59}$

\subsection{Investment treaties and arbitration, the 'regulatory chill' debate and national democratic space}

The second dimension concerns the extent to which international investment law can affect policy options, and ultimately democratic space. The adoption of some comprehensive trade treaties has been associated with rapid, far-reaching national

55 Schneiderman, supra note 35, at 926; Bonnitcha, supra note 5, at Ioo.

56 See, e.g., Hesham Talaat M. Al-Warraq v. The Republic of Indonesia (Final Award, I5 December 20I4), UNCITRAL (arbitration under the Organisation of Islamic Cooperation Investment Agreement).

57 For a critique highlighting the power of corporate lobbying in public decision-making, see Schneiderman, supra note 35.

58 For a discussion of how political economy factors can influence the effectiveness of affirmative action measures, see, e.g., A.M. Goetz, 'No Shortcuts to Power: Constraints on Women's Political Effectiveness in Uganda', (2002) 40(4) Journal of Modern African Studies 549-75.

59 Other claims to legitimacy for the international investment regime, particularly the argument that investment treaties promote foreign investment and ultimately economic growth, are outside the scope of this article. On the (mixed) evidence concerning this point, see, e.g., K.P. Sauvant and L. Sachs (eds.), The Effect of Treaties on Foreign Direct Investment: Bilateral Investment Treaties, Double Taxation Treaties, and Investment Flows (2009). 
law reforms aimed at giving effect to treaty commitments. This has raised questions about space for democratic deliberation in situations where time pressures can be intense and parliament may delegate to the executive extensive legislative powers. ${ }^{60}$ On the other hand, debates linking the international investment regime to national democratic space have centred on whether substantive standards and legal remedies to protect foreign investment can make it more difficult for authorities to act in the public interest - a concern commonly referred to as 'regulatory chill' ${ }^{6 \text { I }}$

That international treaties can restrict available policy options should not surprise: governments may be legally required to take some measures, and proscribed from taking others. Treaties create legally binding obligations, and a state cannot invoke national law, 'no matter how democratically established', to justify non-compliance with its international treaty commitments. ${ }^{62}$ Beyond these general considerations, however, several factors have placed investment treaties and arbitration at the centre of global debates about appropriate balances between corporate and public interests. These factors include the ability of foreign investors to challenge public action by directly accessing international investor-state arbitration; the openly worded investment protection standards contained in many investment treaties, which delegate considerable power to the arbitral tribunals interpreting those standards; and the growing number of actual arbitrations affecting an increasingly wide range of policy areas - including taxation, industrial policy, public health, redistributive reform and environmental protection, to name but a few. In turn, these factors raise issues of democratic governance, because arbitral tribunals usually comprising three private individuals are called to review the conduct of democratically elected governments or legislatures, or of national courts, based on treaty standards that leave significant scope for discretion. ${ }^{63}$ In practice,

60 To implement the Peru-United States Free Trade Agreement (Washington DC, I2 April 2006, available at ustr.gov/trade-agreements/free-trade-agreements/peru-tpa/final-text), the Peruvian government enacted tens of legislative decrees within a few months, based on the delegation of legislative powers from parliament. The process triggered protests and violent clashes. See Report of the Special Rapporteur on the Situation of Human Rights and Fundamental Freedoms of Indigenous People, S.J. Anaya - Addendum: Observations on the Situation of the Indigenous Peoples of the Amazon Region and the Events of 5 June and the Following Days in Bagua and Utcubamba Provinces, Peru, UN Doc. A /HRC/I2/34/Add.8 (2009), at 8-20, available at documents-dds-ny.un.org/doc/UNDOC/GEN/Gog/I50/32/PDF/Go9I5032.pdf?OpenElement.

6I There is a vast literature on this issue. See, e.g., High Commissioner for Human Rights, Human Rights, Trade and Investment, UN Doc. E/CN.4/Sub.2/2003/9 (2003), at 35, available at documents-dds-ny.un.org/doc/UNDOC/GEN/Go3/I48/47/PDF/G03I4847.pdf?OpenElement; S.W. Schill, 'Do Investment Treaties Chill Unilateral State Regulation to Mitigate Climate Change?', (2007) 24(5) Journal of International Arbitration 469-77; K. Tienhaara, The Expropriation of Environmental Governance: Protecting Foreign Investors at the Expense of Public Policy (2009); K. Tienhaara, 'Regulatory Chill and the Threat of Arbitration: A View from Political Science', in C. Brown and K. Miles (eds.), Evolution in Investment Treaty Law and Arbitration (20II), 606-28; Bonnitcha, supra note 5, at II3-33; C. Tietje and F. Baetens, 'The Impact of Investor-State-Dispute Settlement (ISDS) in the Transatlantic Trade and Investment Partnership', (20I4) Study prepared for the Ministry of Foreign Affairs, The Netherlands, available at bit.ly/rjbnTTo; L. Cotula, 'Do Investment Treaties Unduly Constrain Regulatory Space?', 9 Questions of International Law I9-3 I, available at www.qil-qdi.org/wp-content/uploads/2014/II/03_Regulatory-Powers-IEL_COTULA.pdf.

62 Crawford, supra note 8, at 96. See I969 Vienna Convention on the Law of Treaties, 8 ILM 679 (I969) (VCLT), Arts. 26-27.

63 For a discussion of these issues, see Interview with Toby Landau QC, 28 March 20I4, available at www.youtube.com/watch?v=bJaoADpICjs. 
damages are the main remedy available to investors under investor-state arbitration, meaning that states can ultimately take action so long as they compensate investors. ${ }^{64}$ But critical commentators have raised concerns that the risk of exposure to arbitration claims - possibly involving substantial liabilities in compensation and/or legal costs - might reduce the options public authorities can consider in practice, thereby 'shrinking democratic space'. ${ }^{65}$

Much scholarly literature about regulatory chill has focused on doctrinal discussions of treaty formulations and their arbitral interpretation. However, empirically observing the perceptions and behaviour of public authorities is critical in determining whether those authorities consider the risk of arbitration claims in their decision-making processes, and how this circumstance affects options for public action. Methodological challenges constrain systematic evidence, because information about government action and its motivations is often not in the public domain, and because counterfactuals - whether authorities would have acted differently in the absence, or presence, of an applicable investment treaty - are typically not available. ${ }^{66}$ In addition, biases undermine the evidence base, for example because it is easier to find out about the cases where authorities did act, resulting in publicly reported investor-state arbitrations. Overall, there are examples of governments both seeking advice on arbitration risks before enacting proposed measures, and maintaining measures in the face of arbitration threats or claims. ${ }^{67}$ Evidence suggesting that many government officials in low- and middle-income countries have only a limited understanding of investment treaties and their implications ${ }^{68}$ would militate to qualify the extent of regulatory chill, though awareness may grow as the number and reach of arbitrations increase. Socio-legal studies and media reports do suggest that, on some occasions at least, the risk of arbitration claims was a consideration in policy making, highlighting the need not to be complacent about the restrictions that the investment regime can create. Examples include institutionalized arrangements for legal vetting of proposed legislation, ${ }^{69}$ and reports that arbitration risks may have affected

64 Legal scholarship has noted that arbitral tribunals have the power to order specific performance, but in practice most awards involve monetary damages. C. Schreuer, 'Non-Pecuniary Remedies in ICSID Arbitation', (2004) 20(4) Arbitration International 325-32; F.R. Dizgovin, 'Foundations of Specific Performance in InvestorState Dispute Settlement: Is It Possible and Desirable?', (20I6) 28 Florida Journal of International Law I-68. For an instance where the arbitral tribunal ordered specific performance (land restitution), albeit allowing the state to pay damages instead, see, e.g., Bernard Von Pezold and Others v. Zimbabwe (Award, 20I5) ICSID Case No. $\mathrm{ARB} / \mathrm{IO}_{\mathrm{I}}$ 5, at I02O. Arbitral tribunals have recognized the implications of specific performance awards for democratic governance. See, e.g., Achmea B.V.v. The Slovak Republic, Award on Jurisdiction and Admissibility, PCA Case No. 2013-I2 (2014), at 96, 25I.

65 Schneiderman, supra note 35, at 910. See also William Ralph Clayton, William Richard Clayton, Douglas Clayton, Daniel Clayton and Bilcon of Delaware Inc. v. Government of Canada, Award on Jurisdiction and Liability Dissenting Opinion of Professor Donald McRae, PCA Case No. 2009-04 (20I5), at 48, 5 I (expressing the concern that the majority's decision on liability may have a chilling effect on environmental impact assessment review processes).

66 Bonnitcha, supra note 5 , at $\mathrm{I}$ I3-33.

67 Ibid.

68 L.N.S. Poulsen, Bounded Rationality and Economic Diplomacy: The Politics of Investment Treaties in Developing Countries (2015).

69 G. Van Harten and D.N. Scott, 'Investment Treaties and the Internal Vetting of Regulatory Proposals: A Case Study from Canada', (20I6) 7(I) Journal of International Dispute Settlement 92-I I6 (discussing how Canadian government officials consider legal risks in policy processes). 
law making or public action in diverse policy areas such as public health, ${ }^{70}$ banking regulation, ${ }^{71}$ environmental protection, ${ }^{72}$ and the issuance of natural resource concessions. ${ }^{73}$

The focus of regulatory chill debates on measures adopted by governments or parliaments implies a rules-based perspective that connects democratic processes to formalized action by public authorities. An action-based perspective broadens the horizon to also consider opportunities for contestation and negotiation involving a wider range of actors seeking to influence public decision-making. Some international investment law scholarship casts the state either as a benevolent regulator unduly constrained by international investment law, or as an opportunistic predator requiring international discipline. In practice, diverse political economy factors produce complex patterns of state conduct that, depending on the circumstances, may - or may not - advance local or public interests. ${ }^{74}$ Pressure from organized citizens can therefore be an important factor in public action. In this context, public contestation of issues related to ongoing or proposed investments can manifest itself in direct action (e.g., protests, occupations) or court proceedings that could engage investment protection standards. Protests or occupations have been at stake in several arbitrations, with investor claims challenging related or subsequent state

70 Legal action against Australia over plain packaging legislation would appear to have been a consideration in the adoption of anti-smoking legislation in New Newland, with the New Zealand government announcing that it 'will wait and see what happens with Australia's legal cases, making it a possibility that if necessary, enactment of New Zealand legislation and/or regulations could be delayed pending those outcomes': 'Government moves forward with plain packaging of tobacco products', New Zealand Government Press Release, I9 February 2013, available at www.beehive.govt.nz/release/ government-moves-forward-plain-packaging-tobacco-products. Known 'legal cases' against Australia included an investor-state arbitration, and proceedings at the World Trade Organization. See also L.E. Peterson, 'First Hearing in Philip Morris v. Australia Arbitration is Pushed into 2014, as New Zealand Reveals it is Awaiting Outcome of Australian Cases', Investment Arbitration Reporter, 28 February 2013, available at www.iareporter.com/articles/20130228_2. Three years later, after the investor-state arbitration was dismissed, the New Zealand government announced that the legislation would go ahead. S. Kirk, 'Tobacco Plain Packaging Likely to be Law by End of Year - John Key', Stuff, I 5 February 20I6, available at www.stuff.co.nz/national/politics/76917027/Tobacco-plain-packaging-likely-to-be-law-by-end-of-yearJohn-Key.

${ }_{71}$ For reports that threats of arbitration by foreign-owned banks may have contributed to watering down proposed banking legislation in Poland, see C. Wiśniewski and O. Górska, 'A Need for Preventive Investment Protection?', Kluwer Arbitration Blog, 30 September 2015, available at kluwerarbitrationblog.com/blog/20I5/og/30/a-need-for-preventive-investment-protection/.

72 On exemptions the Indonesian government granted, ultimately through a legislative amendment, to companies operating open-pit mines in forest areas after the adoption of more stringent forest legislation and reported arbitration threats, see S.G. Gross, 'Inordinate Chill: BITs, Non-NAFTA MITs, and Host-State Regulatory Freedom: An Indonesian Case Study', (2003) 24(3) Michigan Journal of International Law 893-960; K. Tienhaara, 'What You Don't Know Can Hurt You: Investor-State Disputes and the Protection of the Environment in Developing Countries', (2006) 6(4) Global Environmental Politics 73, at 87-96.

73 On the reported rekindling of parliamentary debates about proposed legislation to ban metals mining in El Salvador after the dismissal of an investor-state arbitration, see, e.g., Diario Co Latino, 'Minería: Señal Positiva', I2 January 2017, available at www.diariocolatino.com/mineria-senal-positiva/.

74 For a fuller discussion, see L. Cotula, "Land Grabbing” and International Investment Law: Toward a Global Reconfiguration of Property?', in A.K. Bjorklund (ed.) Yearbook on International Investment Law \& Policy 201420I5 (2016), I77-2I4, available at pubs.iied.org/Go409I/. 
conduct, ${ }^{75}$ and so have court proceedings initiated by NGOs or grassroots groups. ${ }^{76}$ Similarly, government action in response to NGO advocacy and subsequent parliamentary debates reportedly led to threats of investor-state arbitration. ${ }^{77}$ One question is whether investment protections can make it more difficult for citizens to obtain what they seek. Again, methodological challenges constrain systematic evidence; but reports suggest that, on some occasions at least, concerns about costly arbitration proceedings may have been a factor in government responses to public protests. $^{78}$

The factual circumstances of some arbitrations illustrate how the unfolding of political mobilization can put pressure on legal requirements and prescribed procedures. But arbitral jurisprudence arguably also points to a gulf between the mind-set of legally trained arbitrators and the political nature of action-based democracy. Investments in some sensitive sectors - land and natural resources, for example can raise highly emotive and inherently political issues, especially where natural resources provide an important basis for rural livelihoods and social identity. Mobilization of political figures, in government or opposition, is a common strategy advocacy groups pursue to contest investment issues - particularly where national law provides limited avenues for 'juridified' contestation. ${ }^{79}$ In other words, a degree of politicization may be a fact of life when action-based democracy is applied to investment issues. One question is how arbitral tribunals square these political dimensions with respect for the rule of law. Some tribunals have taken issue with inflammatory statements, political rallies, or action taken under public pressure or against the backdrop of electoral campaigns, ${ }^{80}$ leading some commentators to criticize the tribunals' perceived 'ambivalence, if not outright disdain, for the results of democratic processes'. ${ }^{81}$ However, other tribunals have recognized that 'it is

75 For example, the arbitration Vestey Group Limited included claims that the government failed to protect the agribusiness venture from farm occupations. Vestey Group Limited v. Bolivarian Republic of Venezuela (Award, 20I6) ICSID Case No. ARB/o6/4, at paras. 62-5, 73, 80-2. For an earlier arbitration involving allegations of farm occupations, see, e.g., Tradex Hellas S.A. v. Albania (Award, I999) ICSID Case No. ARB/94/2. Public protests featured in the facts of several arbitrations. See, e.g., Técnicas Medioambientales Tecmed SA v. The United Mexican States, supra note 48, paras. 42, 49, I05(4)-(5), I06-Io, I 27-44; Abengoa S.A. y COFIDES S.A. v. Estados Unidos Mexicanos, supra note 6, paras. I94-208, 587; Copper Mesa Mining Corporation v. The Republic of Ecuador, Award, PCA Case No. 20I 2-2 (20I6), paras. 4.I 2, 4.32-5, 4.45, 4.52, 4.57, 4.69, 4.72, 4.82, 4.87, 4.95, 4.IO7, 4.III-I 2, 4.II 5, 4.I II, 4.I 54-5, 4.I94-5.

76 For examples of arbitrations where court litigation initiated by NGOs or local residents feature prominently, see the ongoing cases Chevron Corporation and Texaco Petroleum Corporation v. The Republic of Ecuador (PCA Case No. 2009-23), and Infinito Gold Ltd. v. Republic of Costa Rica (ICSID Case No. ARB/I 4/5).

77 Z. Williams, 'Investigation: As Colombia Pushes for Cancer Drug Price-Cut and Considers Compulsory Licensing, Novartis Responds with Quiet Filing of an Investment Treaty Notice', Investment Arbitration Reporter, 30 November 20I6, available at www.iareporter.com/articles/investigation-ascolombia-pushes-for-cancer-drug-price-cut-and-considers-compulsory-licensing-novartis-respondswith-quiet-filing-of-an-investment-treaty-notice/.

78 See, e.g., M. Taj, 'Peru Hopes to Revive Bear Creek Mine, Avoid Legal Battle', Reuters, I4 August 20I 4, available at www.reuters.com/article/peru-bear-creek-minng-santaana-idUSL2NoQLooZ2OI408I5 (reporting that the Peruvian government 'hope[d] to ease local opposition to [a] silver mine and avoid a costly legal battle with the company').

79 See, e.g., E. Polack, L. Cotula, and M. Côte, Accountability in Africa's Land Rush: What Rolefor Legal Empowerment? (2013), 37-8.

80 See, e.g., Vivendi II, supranote 6, paras. 7.4.I 8-7.4.46, 7.5.8; Biwater Gauff, supranote 6, at 497-500, 5I 9; Abengoa, supra note 6, at I92-297, 572-610.

8I Schneiderman, supra note 35 , at 9 I I (discussing the Tecmed case, supra note 48). 
normal and common that a public policy matter becomes a political issue', and have clarified that politicization does not necessarily result in arbitrary or discriminatory conduct. $^{82}$

To sum up: by establishing standards that public action must comply with, the international investment regime subjects democratically decided measures to legal scrutiny. The foregoing analysis highlights that shifting from purely rules-based perspectives to include consideration of action-based dimensions provides a fuller, more realistic account of this interface between the international investment regime and national democratic space - questioning established assumptions about the marginalization of foreign investors in national polities, and linking concerns about regulatory chill to space for action by organized citizens as well as governments and parliaments. While methodological challenges constrain systematic data and call for additional empirical work, available evidence suggests that investment treaties and arbitration can be a factor in public decision-making. The financial implications of investment treaties and arbitration also raise questions about how the costs of socially desirable measures should be distributed between governments and businesses. In other words, international investment law does matter, and this creates challenges for ensuring democratic oversight of its development - an issue this article now turns to exploring.

\section{DEMOCRACY AND INVESTMENT TREATY MAKING: BRIDGING THE GAP BETWEEN RULES AND ACTION}

The implications of investment treaties and arbitration call for examining opportunities for democratic decision-making in the development of international investment law - particularly investment treaties, which account for the bulk of the norms of contemporary international investment law. A brief discussion of rulesand action-based dimensions points to gaps between formal rules and citizen action in promoting democratic oversight of investment treaty making.

\section{I. A rules-based perspective on investment treaty making: The case of treaty ratification}

A rules-based analysis would tend to focus on the norms of international law and constitutional law that regulate treaty making processes. This would include norms governing the adoption and entry into force of international treaties but also, for example, the rules on public or parliamentary access to information concerning ongoing negotiations. In relation to each polity, these diverse rules cannot be assessed in isolation but must be considered as part of the overall 'package' they are part of. This is because the operation of one rule can have implications for other parts of the package. For the purposes of this analysis, however, space constraints impose a narrower focus, and this section discusses treaty ratification.

82 See AES Summit Generation Limited and AES-Tisza Erömü Kft v. The Republic of Hungary (Award, 20Io) ICSID Case No. ARB/07/22, paras. I0.3.22-I0.3.24, I0.3.34. 
Apart from minimalistic rules about the representation of states at treaty negotiation and signature stages, ${ }^{83}$ international law leaves states with ample latitude to determine the constitutional arrangements through which public authorities can make treaties. International law also allows diverse mechanisms for states to express their consent to be bound by a treaty, including signature, exchange of instruments, ratification, acceptance, approval, and accession. ${ }^{84}$ Ratification is commonly required for treaties having significant political or economic implications, although some investment treaties provide that they enter into force upon signature. ${ }^{85}$ International negotiations are typically conducted by the executive, and requirements for the text agreed by negotiators to be ratified (that is, formally approved) by public authorities in each state party can create space for democratic scrutiny before a treaty produces its legal effects. ${ }^{86}$ Therefore, ratification constitutes one important arena for exploring rules-based dimensions in treaty-making processes. However, a closer examination of ratification rules and practices reveals tensions between an institution that historically emerged to safeguard the prerogatives of the sovereign vis-à-vis their own plenipotentiaries on the one hand, ${ }^{87}$ and the imperatives created by modern democratic societies on the other.

In each state, procedures for ratification are determined by constitutional law, ${ }^{88}$ and it is impossible to do justice to the great diversity of constitutional configurations in the space allowed here. Overall, the institutions of representative democracy - particularly the roles of government and parliament in treaty ratification - emerge as a key issue in rules-based perspectives. In polities where governments are democratically elected, formal ratification by the cabinet might itself be deemed to provide a tool for democratic governance: from a rules-based standpoint, a democratically elected government represents the interests and aspirations of the people. But even in multi-party polities with genuinely free and fair elections, electoral mandate alone is a blunt instrument to channel the citizens' diverse views on multiple policy issues over a four or five-year mandate period. ${ }^{89}$ As a constitutional organ that, in democratic polities, is likely to reflect a wider range of political positions than those advanced by the executive, parliament can provide a more open space for democratic oversight of investment treaty making. In many polities, parliamentary approval is

83 VCLT, supra note 62, Art. 7.

84 Ibid., Arts. I I-I6

85 See, e.g., I990 Agreement between the Government of the United Kingdom of Great Britain and Northern Ireland and the Government of the Republic of Burundi for the Promotion and Protection of Investments, UK Treaty Series or I/I99I Cmi420 (I99I), Art. I3. I would like to thank James Harrison at Edinburgh Law School for commenting on an earlier draft of Section 4.I and for bringing this example to my attention.

86 J.Wouters, B. De Meester, and C. Ryngaert, 'Democracy and International Law',(2004)Leuven Interdisciplinary Research Group on International Agreements and Development Working Paper No. 5, at 34.

87 M.N. Shaw, International Law (2008), $9 \mathrm{I}$ I.

88 However, VCLT clarifies that: 'A State may not invoke the fact that its consent to be bound by a treaty has been expressed in violation of a provision of its internal law regarding competence to conclude treaties as invalidating its consent unless that violation was manifest and concerned a rule of its internal law of fundamental importance'. VCLT, supra note 62, Art. 46(I).

Wouters, et al., supra note 86 , at 35 . 
an explicit legal requirement for ratification - in the EU and the US, for example. ${ }^{90}$ However, several constitutions around the world allow the cabinet to ratify treaties with little or no parliamentary involvement, and depending on the jurisdiction less demanding parliamentary approval requirements may apply to standalone investment treaties compared to more encompassing trade and investment treaties. ${ }^{9 \mathrm{I}}$

In some jurisdictions, there is no legal requirement for parliament to approve treaty ratification, but the government must lay treaties before parliament for a specified period of time before it can ratify them, and parliament can object to ratification. In the United Kingdom (UK), for example, a legal regime along these lines is embodied in Section 20 of the Constitutional Reform and Governance Act of 20Io; codifying and developing pre-existing constitutional practice, this legislation requires the Government to lay treaties before Parliament for 2 I sitting days before ratification. ${ }^{92}$ This arrangement enables some Parliamentary scrutiny of treaties, but gives Parliament considerably weaker powers than would typically apply to the adoption of domestic legislation. Apart from empowering the executive to waive the application of the prescribed Parliamentary process, ${ }^{93}$ UK legislation does not confer upon Parliament effective powers to block ratification: if the House of Lords votes against ratification, the Government can still ratify the treaty; while if the House of Commons votes against ratification, the Government can again lay the treaty before Parliament, stating the reasons why it believes the treaty should be ratified; the House of Commons can object again, and the process can notionally be repeated indefinitely. ${ }^{94}$ In practice, Parliamentary objections may make it politically difficult for the Government to insist on ratification, though if the Government does insist it may prove difficult in practical terms for the House of Commons to block a treaty through indefinitely repeated votes within tight deadlines. In fact, even holding a single debate, let alone an inquiry, a public consultation, or a vote, within the tight timeframe allowed can prove difficult: in 20I4, public campaigning against the ratification of an investment treaty led to a Parliamentary debate in the House of Lords, but only after the treaty had already been ratified. 95

In any case, ratification intervenes at a late stage in the treaty making process. At that point, parliament usually cannot amend a treaty - it can only approve or

90 Consolidated Version of the Treaty on the Functioning of the European Union, Official Journal of the European Union 2012/C326/or (20I2), Arts. 207(2)-(3) and 2I8(6); US Constitution, Art. II(2)(2).

9I For a global synopsis of constitutional provisions on treaty ratification, see B.A. Simmons, Mobilizing Human Rights: International Law in Domestic Politics (2009), App. 3.2, available at scholar.harvard.edu/ bsimmons/mobilizing-for-human-rights.

92 See J. Barrett, 'The United Kingdom and Parliamentary Scrutiny of Treaties: Recent Reforms', (20II) 60 International and Comparative Law Quarterly 225-45.

93 The Act provides that Section 20 does not apply if a Minister 'is of the opinion that, exceptionally, the treaty should be ratified without the requirements of that section having been met'. Constitutional Reform and Governance Act of 2010, Section 22.

94 Ibid., Section 20(3)-(8).

95 See House of Lords, 'The Bilateral Agreement for the Promotion and Protection of Investments between the United Kingdom and Colombia', 30 July 2014, available at www.publications. parliament.uk/pa/ld20I4I5/ldhansrd/text/I40730-gcooor.htm. The treaty debated was the 20Io Bilateral Agreement for the Promotion and Protection of Investments between the Government of the United Kingdom of Great Britain and Northern Ireland and the Republic of Colombia, UK Treaty Series 024/2014 Cm8973 (20I4). 
reject it, though parliament might be able to insist on certain reservations to be made if the treaty in question allows this. ${ }^{96}$ There are examples of parliamentary rejection, or pre-emptive government action to avoid formal rejection: the European Parliament rejected a major anti-counterfeiting agreement, ${ }^{97}$ and in the I 990 os Brazil signed several investment treaties but brought none of them into force partly due to opposition in Congress. ${ }^{98}$ Further, the perceived risk that parliament might not approve a treaty unless some provisions are included could influence negotiations before the treaty is signed..$^{99}$ In practice, however, it is often difficult to reject treaties in their entirety, because significant time and resources may have been invested in their negotiation, advantageous provisions may be perceived to offset problematic ones, and a rejection could damage important international relations. Significant time pressures may also be at play, further reducing the scope for meaningful parliamentary activity. Overall, this analysis lends support to the thesis that, 'even democratic States suffer from a considerable democratic deficit'. ${ }^{\text {Ioo }}$

Another common argument about safeguards for rules-based democracy in international treaty making is the fact that, in 'dualist' jurisdictions, a ratified treaty creates binding obligations on the international plane but can only produce effects in the domestic legal order if it is incorporated into national law, which depending on the jurisdiction may require an act of parliament. ${ }^{\text {IOI }}$ The adoption of legislation to implement a treaty creates additional opportunities for parliamentary and possibly public debate. However, apart from the intrinsic limitations of this approach in promoting democratic oversight of policy decisions that establish international constraints 'upstream' of national legislation, ${ }^{\text {I02 }}$ these features are of limited relevance to international investment law. Indeed, investment treaties typically enable investors to bring alleged breaches of treaty standards to international investor-state arbitration, rather than (or in addition to) domestic courts. Instead of entrenching international commitments into national law, these arrangements effectively aim to shelter the investment protection regime from the operation of national law. One rationale for this approach is that public authorities can change national law in ways that could be detrimental to investors or their investments, so national

96 Wouters, et al., supra note 86 , at $34-5$.

97 European Parliament Res. of 4 July 2012 on the Draft Council Decision on the Conclusion of the Anti-Counterfeiting Trade Agreement between the European Union and its Member States, Australia, Canada, Japan, the Republic of Korea, the United Mexican States, the Kingdom of Morocco, New Zealand, the Republic of Singapore, the Swiss Confederation and the United States of America (I2I95/20II - C7-0027/20I 2 - 20II/OI67(NLE)), European Parliament Doc. P7 TA(2012)0287, available at www.europarl.europa.eu/sides/getDoc.do?pubRef=-//EP//TEXT+TA+P7-TA-20 2-0287+O+DOC+XML+ Vo//EN.

98 Trade Policy Review - Brazil, World Trade Organization Doc. No. WT/TPR/S/283 (20I3), at 2.29, available at www.wto.org/english/tratop_e/tpr_e/s283_e.pdf.

99 This consideration may well have played a role in the amendments made to the investor-state dispute settlement provisions of CETA, supra note II. See, e.g., D. Vincenti, 'EU, Canada Change ISDS Clause, Get Closer to "Gold-Plated Trade Deal”, EurActiv, 29 February 20I6, available at www.euractiv. $\mathrm{com} /$ section/trade-society/news/eu-canada-change-isds-clause-get-closer-to-gold-plated-trade-deal/ (citing the EU Commissioner as expressing confidence that the revised text would meet 'the expectations ... of the European Parliament').

Ioo Wouters, et al., supra note 86 , at 35 .

ror De Mestral and Fox-Decent, supra note 9, at 58I.

I02 Kurtz, supra note 54, at 260. 
law is deemed to provide only limited reassurance. While this argument does have merit, the point here is that the arrangement reduces or even eliminates the need for incorporating the treaty into national law, and with that the opportunities for parliamentary debate that may be associated with adopting legislation to domesticate international treaties into the national legal order.

These rules-based aspects tend to focus on the relationship between the executive and the legislature. They emphasize the role of the institutions of representative democracy in treaty ratification. Formal opportunities for more direct citizen engagement seem rare, but examples exist. In 2007, for example, Costa Rica held a referendum on a trade and investment treaty, the Dominican Republic - Central America United States Free Trade Agreement (CAFTA). ${ }^{\text {I03 }}$ The 'yes' vote won by a narrow margin, paving the way to Costa Rica's ratification of the treaty. Formal public consultations on investment treaties may also provide an avenue. One example (not relating to treaty ratification) is the carefully-circumscribed online consultation launched by the European Commission on the investment chapter of the proposed TTIP. ${ }^{\text {I04 }}$

This analysis points to considerable diversity among jurisdictions, but also to some limitations of international and constitutional rules in providing opportunities for democratic oversight of investment treaty making. Arguably, the fundamental framing of rules on ratification largely emerged at a time when international law had more limited reach than is the case for contemporary international economic treaties. Depending on the circumstances, ratification may not be required, it may only involve approval at the government level, or else it may create some opportunity for parliamentary scrutiny at a late stage in the process or under intense time pressures. In some polities, recent evolutions have increased opportunities for parliament or even the electorate to have a say in treaty ratification, and robust parliamentary powers at the ratification stage can affect earlier phases of treaty making. Depending on the jurisdiction, however, the legal channels for parliament to shape investment treaties may pale in comparison to the central role of parliament in developing national legislation; while formalized opportunities for citizens to have a say in investment treaty making outside parliamentary processes tend to be very limited.

\subsection{An action-based perspective on investment treaty making}

Moving the focus from a rules-based to an action-based conception of democracy unlocks insights on important but often neglected aspects concerning the workings of democratic processes. In relation to investment treaty making, an action-based perspective would encompass public and parliamentary debate on fundamental policy choices upstream of individual treaty negotiations, and public and parlia-

I03 2004 Dominican Republic-Central America-United States Free Trade Agreement, 43 ILM 5 I 4 (2004), available at ustr.gov/trade-agreements/free-trade-agreements/cafta-dr-dominican-republic-central-america-fta/finaltext.

ro4 European Commission, 'Online Public Consultation on Investment Protection and Investor-toState Dispute Settlement (ISDS) in the Transatlantic Trade and Investment Partnership Agreement (TTIP)', (20I5) Commission Staff Working Document 2015/3, available at trade.ec.europa.eu/ doclib/docs/20I5/january/tradoc_I53044.pdf. 
mentary scrutiny throughout the negotiation and ratification process. Again, space constraints only allow for a few broad brushstrokes, and the lack of systematic evidence prevents a comprehensive analysis of trends.

In the late I99os, the negotiation of the Multilateral Agreement on Investment prompted NGO campaigning in several high-income countries, which partly contributed to the failure of the negotiations. ${ }^{\text {I05 }}$ Overall, however, historical patterns seem to point to very little citizen engagement with investment treaty making, particularly in low- and middle-income countries. Many governments handled investment treaty making as a technocratic process, and it seems plausible to speculate that many of the over 3,000 treaties constituting the global investment treaty network were concluded with little public debate about the costs and benefits of treaty negotiation and ratification. Indeed, research on investment treaty making in low- and middle-income countries has cast doubt on whether government officials themselves fully considered the costs and benefits of the treaties. ${ }^{106}$ There are no comparable studies assessing the extent to which parliaments and citizens at large understood, considered, and debated those costs and benefits; but if the debates occurred, little trace of them appears to be left. It has been noted that even in 'mature' democracies such as the US and the EU economic treaties 'often receive far less democratic scrutiny than domestic legislation with the same socio-economic redistributive impact'. ${ }^{\text {I07 }}$

Multiple factors may explain this situation. International investment law involves complex technical issues and, until the relatively recent rise of investor-state arbitration, investment treaty making remained a largely obscure area of international law. Practical constraints can affect parliamentary scrutiny. Where parliaments do have constitutional powers on treaty ratification, competing demands on parliamentary time and resources can prevent them from making full use of those powers, and parliamentary votes are not necessarily preceded by full debate of the relevant issues. ${ }^{108}$ Where parliament and the executive are politically aligned and party discipline is strong, scope for independent scrutiny would tend to be reduced. ${ }^{\text {Iog }}$ Practical constraints can affect citizen action too. Public awareness of investment treaties is often limited, as is publicly available information about developments in treaty negotiations, and concerns have been raised about asymmetries in access to information between business and advocacy groups. ${ }^{\text {IIO }}$ Under such circumstances, ensuring quality in any deliberative processes can present significant

I05 J. Kurtz, 'NGOs, the Internet and International Economic Policy Making: The Failure of the OECD Multilateral Agreement on Investment', (2002) 3 Melbourne Journal of International Law 2 I 3-46.

Io6 Poulsen, supra note 68.

I07 Weiler, supra note 4 , at 556.

ro8 See the example of the Korean ratification of the US-Korea Free Trade Agreement, discussed in Y. Kim, 'The Policy and Institutional Framework for FTA Negotiations in the Republic of Korea', in J. Harrison (ed.), The European Union and South Korea (2013), 4I, at 49-52. On the difficulties of holding a parliamentary debate in the United Kingdom before the Colombia-UK investment treaty was ratified, see supra note 95.

ro9 D. Jančić, 'TTIP and Legislative-Executive Relations in EU Trade Policy', (2016) 4O(I) West European Politics 202, at 205, 207, 2 I 6.

in H. Mann, 'The TTIP, Part I: A Deal Too Far', International Institute for Sustainable Development Commentary, January 20I6, available at www.iisd.org/sites/default/files/publications/tpp-part-i-deal-toofar-commentary_i.pdf, at $4-5$. 
challenges. Even Costa Rica's experience with holding a referendum before ratifying CAFTA, discussed above, has not been without critics. Some commentators pointed to the pressures exercised by business groups during the referendum campaign, and to significant asymmetries in the financing of the 'yes' and 'no' campaigns, going as far as arguing that these circumstances 'made the referendum appear as a tool for citizen manipulation rather than an instance of informed citizen participation'. ${ }^{\text {II }}$ Finally, the asymmetric negotiating power relations that often characterize treaty negotiations, particularly between low- and high-income countries, would tend to further shrink the scope for citizens in low-income countries to influence treaty making. ${ }^{\text {I } 2}$

Democratic oversight issues in treaty making also apply to other areas of international law, and to the international as well as the national plane. On the international plane, treaty negotiations in general tend to be conducted between relevant government departments, often with limited public scrutiny and participation, and investment treaties are no exception to this trend. However, the past 25 years have witnessed shifts in several areas of international law making. Major multilateral treaty conferences are increasingly attended by non-state actors - particularly in environmental diplomacy, but also in the areas of human rights and international criminal law. ${ }^{\mathrm{II} 3}$ Conference attendance does not necessarily translate into meaningful access to information, and NGOs have highlighted the challenges they face in multilateral environmental diplomacy. ${ }^{\mathrm{II} 4}$ Nonetheless, the shift seems significant. The decentralized structure of investment treaty making, coupled with possible concerns about the confidentiality of commercial negotiations, reduce space for comparable developments - and investment treaty negotiations have not experienced a similar opening up. ${ }^{\text {II5 }}$ The low levels of public oversight in investment treaty making create challenges for democratic governance, and a UN Independent Expert went as far as openly questioning the democratic legitimacy of the international investment regime. ${ }^{\text {II } 6}$

That said, democratic scrutiny of investment treaty making has evolved significantly in recent years, particularly in the context of negotiations among

II A. Breuer, 'Costa Rica’s 2007 Referendum on the Dominican Republic - Central American Free Trade Agreement (CAFTA-DR): Citizen Participation or Manipulation?', (2009) 45(4) Representation 455, at 464.

II2 Weiler, supra note 4, at 556.

II3 For example, many NGOs attended the UN Diplomatic Conference of Plenipotentiaries on the Establishment of an International Criminal Court (Rome, I5 June-I7 July 1998). See De Mestral and Fox-Decent, supra note 9, at 59I, and Non-Governmental Organizations Accredited to Participate in the Conference, UN Doc. A/CONF.I83/INF/3 (I998).

II S. Duyck, 'Promoting the Principles of the Aarhus Convention in International Forums: The Case of the UN Climate Change Regime', (2015) 22(4) Review of European, Comparative and International Environmental Law I23, at I3I.

II5 See, however, the information disclosed, the advisory group established and the stakeholder events held in connection with TTIP negotiations. Transatlantic Trade and Investment Partnership: Documents and Events, European Commission Online, available at ec.europa.eu/trade/policy/in-focus/ttip/ documents-and-events/index_en.htm.

II6 Report of the Independent Expert on the Promotion of a Democratic and Equitable International Order, UN Doc. A/70/285 (20I5), at Io, available at www.un.org/en/ga/search/view_doc.asp?symbol=A/70/285. See also Report of the Special Rapporteur of the Human Rights Council on the Rights of Indigenous Peoples on the Impact of International Investment and Free Trade on the Human Rights of Indigenous Peoples, UN Doc. A/70/30I (2015), at 52-5, available at www.un.org/ga/search/view_doc.asp?symbol=A/70/30I. 
medium- and high-income polities that offer space for political contestation. The institutions of representative democracy have provided an important arena for these developments. As investor-state arbitrations highlight the implications that investment treaties can have in a wide range of policy areas, some parliaments are taking a more proactive role in investment treaty making, and NGOs have put pressure on parliaments to do so. ${ }^{\text {II7 }}$ In the EU, after the Lisbon Treaty came into effect, ${ }^{\text {II } 8}$ the European Parliament has leveraged its greater say in economic treaty making to provide specific guidance on investment treaty policy, ${ }^{\mathrm{II} 9}$ and on individual treaty negotiations, ${ }^{\mathrm{I} 20}$ upstream of the actual negotiations. The integration of investment issues into wider economic partnership agreements has arguably fostered parliamentary interest, because of the more wide-ranging policy issues at stake: in Europe, the negotiation of the proposed TTIP with the US was accompanied by a flurry of parliamentary activity, both at the EU level and in EU member states, ${ }^{\mathrm{I} 2 \mathrm{I}}$ with investment protection proving a significant sticking point. ${ }^{122}$ Several parliamentary inquiries offered opportunities for input by external experts and organized citizens. In the UK, for example, both the House of Lords and the House of Commons conducted inquiries on TTIP, including its investment provisions, and where relevant they raised issues with EU negotiators. ${ }^{123}$ In some cases at least, national parliamentary activities fed into the development of the negotiating mandate by the Council, in which national governments are represented. ${ }^{\text {I24 }}$

This proactive role of parliaments has come into tension with restrictions on access to information, ${ }^{\mathrm{I} 25}$ and limited levers for parliaments to ensure proper

I17 Trade Justice Movement, 'Bilateral Investment Treaties - Not Fit for Purpose: The Case for Reform', (2016) MP Briefing October 20I6, available at www.tjm.org.uk/trade-issues/related-campaignissues/bilateral-investment-treaties/374-the-case-for-reform-for-uk-bits-mp-briefing.html.

II 2007 Treaty of Lisbon Amending the Treaty on European Union and the Treaty Establishing the European Community, Official Journal of the European Union 2007/C306 (2007).

I19 European Parliament Res. of 6 April 20II on the Future European International Investment Policy, Procedure File 2010/2203(INI) (20II), available at www.europarl.europa.eu/sides/ getDoc.do?pubRef=-//EP//TEXT+TA+P7-TA-20I I-OI4I+O+DOC+XML+Vo//EN.

I20 See, e.g., European Parliament Res. of 9 October 2013 on the EU-China Negotiations for a Bilateral Investment Agreement, Procedure File 20I3/2674(RSP) (20I3), available at www.europarl.europa.eu/ sides $/$ getDoc.do?type $=$ TA\&language $=$ EN\&reference $=$ P7-TA-20I3-4I $\mathrm{I}$.

I2I Jančić, supra note I09, at 209 (estimating that TTIP has been discussed in no fewer than 32 parliamentary chambers in the EU).

I22 Ibid., at 205, 209-IO, 2 I 4.

I23 See, e.g., House of Commons, Environmental Risks of the Transatlantic Trade \& Investment Partnership - Inquiry Report, Environmental Audit Committee (Io March 2015, HC 857), available at www. publications.parliament.uk/pa/cm20I4I5/cmselect/cmenvaud/857/857.pdf; House of Commons, Letter to EU Trade Commissioner on the Committee's TTIP Report, Environmental Audit Committee (I7 March 20I5), available at www.parliament.uk/documents/commons-committees/environmental-audit/ Letter-trade-commissioner-TTIP.pdf; House of Commons, Transatlantic Trade and Investment Partnership - Inquiry Report, Business, Innovation and Skills Committee (25 March 20I5, HC 804), available at www.publications.parliament.uk/pa/cm20I4I5/cmselect/cmbis/804/804.pdf; House of Lords, The Transatlantic Trade and Investment Partnership - Inquiry Report, European Union Committee (I3 May 20I4, HL I79), available at www.publications.parliament.uk/pa/ld20I3I4/ldselect/ldeucom/ I79/I 79.pdf.

I24 Jančić, supra note I09, at 206, 210, 2 I4.

${ }^{\text {I25 }}$ Access to documents concerning negotiations is often restricted, even for parliamentarians. In relation to TTIP negotiations, public pressures eventually led to an arrangement for the European Parliament to have unrestricted access to the documentation. Framework Agreement on Relations between the European Parliament and the European Commission, Official Journal of the 
follow-up on their deliberations. ${ }^{26}$ It has also been associated with heated public debates about the most appropriate level and timing of parliamentary scrutiny. A few days before the planned signature ceremony of CETA, for example, the vote of a regional parliament in Belgium raised the prospect that the trade deal would be sunk. ${ }^{\text {I27 }}$ Belgian constitutional law requires regional as well as federal parliamentary approval of treaties such as CETA. ${ }^{\text {I28 }}$ The impasse was ultimately overcome after Belgium issued a declaration addressing some of the parliamentarians' concerns, and parliamentary approvals were granted. ${ }^{\text {I29 }}$ The experience suggests that parliamentarians can take very seriously their role in scrutinizing international treaty making. It also illustrates the considerable pressures that parliaments can experience if opportunities for scrutiny occur so late in the process. At the same time, this experience raises questions about the most effective means for enabling parliamentary scrutiny. Time pressures led to a somewhat chaotic unfolding of events, and at one point the Canadian Prime Minister reportedly took a last-minute decision not to board the plane bound for the planned signature ceremony. ${ }^{130}$ The prospect of a body representing a small share of the EU population blocking a treaty backed by all other EU member states led to accusations of 'political hostage-taking,, ${ }^{\text {I3 }}$ and to concerns about 'paralysis' in EU trade and investment policy. ${ }^{\mathrm{I} 22}$ At a deeper level, the fact that constitutional law in other EU member states does not confer comparable powers to regional assemblies in effect gives disproportional political weight to some subnational representative bodies, raising questions about equality among citizens in their ability to influence public decisions.

European Union 2010/L304/47-62 (2010), at Ann. II, point 2.3. See 'All MEPs to Have Access to All Confidential TTIP Documents', European Parliament Press Release, 2 December 2015, available at www.europarl.europa.eu/pdfs/news/expert/infopress/2015I202IPRo5759/20I5I202IPRo5759_en.pdf.

I26 For example, some statements on TTIP issued by EU national parliaments received no or very brief responses from the European Commission. Jančić, supra note Iog, at 2 I4.

I27 J. Rankin, 'EU-Canada Free Trade Deal at Risk after Belgian Parliament Vote', The Guardian, I4 October 20I6, available at www.theguardian.com/business/20I6/oct/I4/eu-canada-free-trade-dealceta-in-jeopardy-belgium-wallonia-parliament-vote. There is controversy about whether such trade and investment treaties fall within the EU's exclusive competence, or whether they are 'mixed' agreements requiring approval by both the EU and its member states. The Court of Justice of the European Union is examining this issue. D. Kleimann and G. Kübek, 'The Future of EU External Trade Policy - Opinion 2/I5: Report from the Hearing', EU Law Analysis, 4 October 2016, available at eulawanalysis.blogspot.co.uk/2016/Io/the-future-of-eu-external-trade-policy.html. Without prejudice to its legal view that the treaties are an 'EU-only' issue, the European Commission proposed CETA as a mixed agreement 'to allow for a swift signature and provisional application'. 'European Commission Proposes Signature and Conclusion of EU-Canada Trade Deal', European Commission Press Release, 5 July 20r6, available at europa.eu/rapid/press-release_IP-I6-237I_en.htm.

I28 Déclaration du Royaume de Bēgique Relative aux Conditions de Pleins Pouvoirs par l'Etat Fédéral et les Entités Fédérées pour la Signature du CETA (27 October 20I6), Section A, available at data.consilium.europa.eu/ doc/document/ST-I3463-20I6-REV-I/fr/pdf.

I29 R.J. Bartunek and P. Blenkinsop, 'Belgium Breaks Deadlock over EU-Canada Trade Pact', Reuters, 27 October 20I6, available at www.reuters.com/article/us-eu-canada-trade-idUSKCNı 2 RoXQ. See also Déclaration $d u$ Royaume de Belgique, supra note I28, Section B. The declaration includes several references to the investment chapter, reflecting the prominence of this chapter in the debate.

I30 J. Rankin, 'Canadian PM Cancels Brussels Trip amid Crisis Talk to Save Trade Deal', The Guardian, 27 October 20I6, available at www.theguardian.com/world/20I6/oct/27/justin-trudeau-canadianpm-cancels-brussels-trip-talks-trade-deal-eu.

I3I Bartunek and Blenkinsop, supra note I29.

I32 D. Kleimann and G. Kübek, "After the "CETA Drama," Toward a More Democratic EU Trade Policy', Politico, I December 20ı6, available at www.politico.eu/article/opinion-after-the-ceta-drama-towarda-more-democratic-eu-trade-policy/. 
Outside parliamentary processes, public scrutiny by organized citizens also seems to be on the rise. Some recent investment treaty negotiations involved significant public mobilization, especially where investment provisions were folded into more encompassing (and as such more visible and potentially impactful) trade and investment treaties. These developments are particularly evident in high-income countries. Advocacy has relied extensively on social media campaigns, media outreach, and public protests, but there is also experience with 'creative' use of legal processes. In Europe, for example, citizens' groups filed a request for a 'European citizens' initiative' on two major proposed economic treaties. A European citizens' initiative is an invitation to the European Commission to propose legislation, which must be backed by at least one million EU citizens coming from at least seven member states. ${ }^{\text {I33 }}$ The citizens' initiative asked the Commission 'to repeal the negotiating mandate for the Transatlantic Trade and Investment Partnership (TTIP)' with the US, and 'not to conclude the Comprehensive Economic and Trade Agreement (CETA)' with Canada. The European Commission rejected this request, finding that it was not in line with EU legislation. ${ }^{\mathrm{I} 4}$ However, NGOs pushed ahead with the petition as a tool to catalyze awareness raising and citizen engagement, and the petition reportedly marshalled over three million signatures. ${ }^{\text {I35 }}$ The investment chapters featured prominently in NGO advocacy on CETA and TTIP, and in response the European Commission proposed an 'investment court system (ICS)' to settle investor-state disputes and negotiated its integration into CETA. ${ }^{136}$ The proposed ICS sparked considerable debate and has so far failed to assuage NGO concerns. ${ }^{\text {I37 }}$

While systematic data is not available, parliamentary and citizen scrutiny of investment treaties appears to remain substantially more limited in many low- and middle-income countries. Nonetheless, documented examples exist. In Malaysia, for example, a coalition of NGOs, consumer groups, public health organizations, and trade associations conducted extensive campaigning, awareness raising, alliance building, and government lobbying to advocate on the investment chapter of the proposed TPP, with parliamentarians also scrutinizing the negotiations. ${ }^{\mathrm{I} 38}$ In

${ }^{2} 33$ The legal basis for the European citizens' initiative is provided by the Consolidated Version of the Treaty on European Union, Official Journal of the European Union 20I2/C326/oI (20I2), Art. I I(4); Treaty on the Functioning of the European Union (as amended), Official Journal of the European Union 2008/CII5/OI (2008), Art. 24(I); Reg. (EU) No 2 I I/20I I of the European Parliament and of the Council of I6 February 20 I I on the Citizens' Initiative, Official Journal of the European Union 20I I/L65/I (20I I).

${ }^{134}$ European Commission, Your Request for Registration of a Proposed Citizens' Initiative Entitled "STOP TTIP”" [motivated refusal to register the citizens' initiative], European Commission Doc. No. C(20I4)650I final (20I4), available at www.ec.europa.eu/citizens-initiative/public/documents/2552.

${ }_{35}$ Williams, supra note $\mathrm{I} 3$.

I36 C. Malmström, 'Proposing an Investment Court System', European Commission Blog, I6 September 2015, available at ec.europa.eu/commission/2014-20I g/malmstrom/blog/proposing-investment-court-system_en. The EU originally proposed the ICS in the context of TTIP negotiations. The proposal was presented as 'an internal document of the European Union', rather than a formal proposal to negotiating partners. Commission Draft Text TTIP - Investment, European Union Internal Doc. I53807 (2015), available at trade.ec.europa.eu/doclib/docs/20I5/september/tradoc_I53807.pdf. For the revised CETA text, see note II, supra.

137 See, e.g., S2B, 'ISDS: Courting Foreign Investors', Analysis by the Seattle to Brussels Network, 29 September 2015, available at www.s2 bnetwork.org/wp-content/uploads/20I5/Io/S2B_ISDS.pdf.

${ }_{138}$ F. Abdul Aziz, Advocacy on Investment Treaties: Lessons from Malaysia (2015), available at pubs. iied.org/I258IIIED.html. 
Myanmar, NGOs conducted advocacy on a proposed bilateral investment treaty with the EU. ${ }^{139}$ In addition, the international nature of investment treaties catalyzed alliance building for citizen engagement beyond the boundaries of nation states. Examples included sharing information and analysis among NGOs active in the I 2 TPP countries, and joint letters calling for greater transparency signed by parliamentarians from several of those countries. ${ }^{\text {I40 }}$

Many investment treaties worldwide continue to be concluded with little public scrutiny. The sustained attention received particularly by some 'mega-regional' negotiations contrasts with the limited public debate that characterizes other treaty making processes, especially bilateral agreements that are more narrowly focused on investment issues. But these developments suggest that, in several polities, citizens and parliaments are increasingly making use of available spaces for debate and influence. They also point to ongoing renegotiations of the relationship between the executive and the legislature in treaty-making processes. This is exemplified by the European Parliament's successful drive to obtain expanded access to TTIP documentation, mentioned above, which begs questions about whether comparable arrangements should apply to other negotiations. In addition, the experience with the proposed European citizens' initiative on CETA and TTIP, then turned into an unofficial petition, illustrates how some citizen actions have been pursued despite their exclusion from formalized processes. This citizen activism raises issues deserving more complete empirical investigation - for example, on the nature and agendas of the actors driving that activism; and whether citizen activism is fostering real policy change, or merely lending democratic legitimacy to policies that present substantial continuity with previous practice. ${ }^{\text {III }}$ From a democratic governance perspective, however, demand for greater citizen and parliamentary scrutiny of investment treaty policy contrasts with the enduring limitations that, depending on the jurisdiction, may characterize the rules shaping formalized opportunities for democratic oversight. Differently put, there are gaps between action-and rules-based dimensions, with legal rules at times struggling to accommodate developments in action-based democracy. The lack of systematically considered rules for citizen and parliamentary activity has also created difficulties in terms of both effective public scrutiny and orderly treaty making, as the Belgium/CETA example illustrates. There is a strong case for reforming the rules, and improving implementation of existing law, so as to augment and clarify opportunities for democratic oversight. Evolutions

I39 See, e.g., 'CSO Statement on Myanmar Investment Treaties', 25 June 20I4, available at www.tni.org/en/declaration/cso-statement-myanmar-investment-treaties; 'Open Letter from Myanmar Civil Society on EU-Myanmar Investment Agreement', Concerns of Myanmar Civil Society on 'Sustainability Impact Assessment' (SIA) in Support of an Investment Protection Agreement between EU and Myanmar, 6 April 20I6, available at www.s2 bnetwork.org/myanmar-sia/.

I40 Abdul Aziz, supra note I38, at 9-IO.

I4I On opposing sides of the debate, see, e.g., allegations that left-leaning politicians 'orchestrated' public mobilization around TTIP in Germany, M. Bauer, 'Manufacturing Discontent: The Rise to Power of Anti-TTIP Groups', (2016) European Centre for International Political Economy Occasional Paper No. 02/2016, available at ecipe.org/app/uploads/20I6/I I/Manufacturing-Discontent.pdf; and continuing NGO dissatisfaction with the 'cosmetic' changes introduced with the ICS, S2B, supra note I37, at Io. 
in investor-state arbitration provide insights on transitions from action to rules, and the analysis now turns to exploring this issue.

\section{Public participation in investor-State arbitration: From ACTION TO RULES?}

In recent years, investor-state dispute settlement has formed the object of much debate, in which strong positions have been taken on issues such as respect for the rule of law and space for democratic control over the management of public affairs. The past ten years have also witnessed major evolutions in the legal rules shaping opportunities for citizen engagement with dispute settlement processes. A vast academic body of literature has emerged on these issues, ${ }^{\mathrm{I}}{ }^{2}$ and there is no need to repeat the analyses developed in those extensive writings. The planned establishment of an ICS, reflected in CETA, has already been mentioned, and if implemented this reform could significantly change the nature of investor-state dispute settlement; but it is still too early to discuss its operation. On the other hand, this section develops a few reflections that highlight a democratic governance perspective in both its rules- and action-based dimensions.

An initial set of questions concerns the appropriateness of a democratic governance framework for discussions about investor-state arbitration. In many national jurisdictions, the judicial function is largely subtracted from the operation of electoral politics, in line with the doctrine of separation of powers. This would at first sight seem to establish neat boundaries between the spheres of adjudication and democratic decision-making. However, setting aside the conceptual implications of the (at least indirect) role of electoral politics in judicial appointments in some jurisdictions, two considerations make a democratic lens relevant to investorstate arbitration. First, investor-state arbitration has been at the centre of public (and particularly non-specialist) debates about investment law and democratic governance, featuring prominently in media reports ${ }^{\mathrm{I} 43}$ and in public advocacy on proposed economic treaties such as TTIP, ${ }^{\mathrm{I} 44} \mathrm{TPP},{ }^{\mathrm{I} 45}$ and the ongoing negotiations of the Regional Comprehensive Economic Partnership (RCEP). ${ }^{\text {I46 }}$ In effect, investor-state

${ }^{142}$ See, e.g., K. Tienhaara, 'Third Party Participation in Investment-Environment Disputes: Recent Developments', (2007) I6(2) Review of European, Comparative \& International Law 220-42; J.A. VanDuzer, 'Enhancing the Procedural Legitimacy of Investor-State Arbitration Through Transparency and Amicus Curiae Participation', (2007) 52 McGill Law Journal 68 I-723; J. Harrison, 'Human Rights Arguments in Amicus Curiae Submissions: Promoting Social Justice?', in P.M. Dupuy, F. Francioni and E.U.Petersmann(eds.), Human Rights in International Investment Law and Arbitration (2009), 396-42 I; E. De Brabandere, 'NGOs and the "Public Interest": The Legality and Rationale of Amicus Curiae Interventions in International Economic and Investment Disputes', (20II) I 2(I) Chicago Journal of International Law $85-$ I I 3.

I43 See, e.g., Robinson, supra note I5.

I44 Williams, supra note $\mathrm{I} 3$.

I45 Public Citizen, 'TPP Leak Reveals Extraordinary New Powers for Thousands of Foreign Firms to Challenge U.S. Policies and Demand Taxpayer Compensation', Public Citizen Press Release, 25 March 2015, available at www.citizen.org/documents/tpp-investment-leak-20I5-release.pdf.

${ }^{146}$ See, e.g., 'Civil Society Groups Say No to Investors Suing States in RCEP', Bilaterals.org, 3 August 2016, available at www.bilaterals.org/?civil-society-groups-say-no-to (reproducing a statement signed by 95 civil society organizations). 
arbitration has come to epitomize public concerns about the relationship between the international investment regime and national democratic space.

Second, issues about the independence, transparency, and integrity of adjudication processes, and about the ability of those processes to include third-party and public interests as may be required, are relevant to an analysis of democratic governance that considers its close relationship with the rule of law. These issues have featured prominently in recent debates about, and critiques of, investor-state arbitration, including in relation to its perceived limited transparency and constrained opportunities for third parties to bring concerns to the attention of arbitral tribunals. ${ }^{\text {I47 }}$ These issues have also constituted important arenas for efforts to address the perceived 'legitimacy crisis' of investor-state arbitration, ${ }^{\mathrm{I}}{ }^{8}$ including measures to increase transparency and enable NGO participation in arbitral proceedings. As discussed, it is important to problematize the equivalence often too quickly drawn between 'democracy in action' and NGO activities, ${ }^{\mathrm{I} 49}$ particularly in contexts where NGOs claim to be bearers of a public interest (often tied to specific institutional mandates) but may operate in the absence of effective arrangements to ensure their own accountability to citizens in the polities where they work. ${ }^{150}$ That said, developments concerning NGO participation in investor-state arbitration provide important and as yet underexplored insights on the interplay between rulesand action-based notions of democracy.

The relevant scholarly literature largely focuses on evolutions in arbitration rules. However, a closer examination highlights the central place of action-based dimensions in efforts to open up investor-state arbitration. The emergence of amicus curiae submissions to arbitral tribunals is a case in point. Non-governmental institutions pioneered these submissions, drawing on experience developed in jurisdictions such

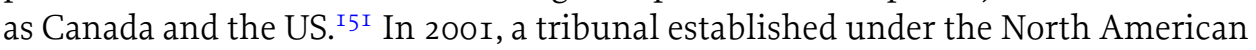
Free Trade Agreement (NAFTA) and operating under United Nations Commission on International Trade Law (UNCITRAL) arbitration rules first decided that it had the power to accept such submissions, and stated that it was 'minded' to accept the submissions made. ${ }^{152}$ The first comparable opening under the arbitration rules of the International Centre for Settlement of Investment Disputes (ICSID) occurred in

I47 For a critique of investor-state arbitration, see G. van Harten, Investment Treaty Arbitration and Public Law (2007).

${ }^{1} 48$ S.D. Franck, 'The Legitimacy Crisis in Investment Treaty Arbitration: Privatizing Public International Law through Inconsistent Decisions', (2005) 73 Fordham Law Review I52 I-625.

I49 Charnovitz, supra note 34.

I50 De Brabandere, supra note I42.

I5I Methanex Corporation v. United States of America (Petition to the Arbitral Tribunal Submitted by the International Institute for Sustainable Development, 25 August 2000), UNCITRAL, NAFTA Ch. I I, available at www.state.gov/documents/organization/3938.pdf. For other documentation about the amicus curiae submissions in this case, see Methanex Corp. v. United States of America: Amicus, United States Department of State Online, 2004, available at www.state.gov/s/l/c582 r.htm.

152 Methanex Corporation v. United States of America (Dec. of the Tribunal on Petitions from Third Persons to Intervene as 'Amici Curiae', 200I), UNCITRAL, NAFTA Ch. II, at 47, 52-3, available at www.italaw.com/sites/default/files/case-documents/ita05I7_o.pdf. On this decision, see H. Mann, 'Opening the Doors, At Least A Little: Comment on the Amicus Decision in Methanex v. United States', (200I) Io Review of European, Comparative and International Environmental Law 24I-5. 
2005. ${ }^{\text {I53 }}$ While spearheaded by non-governmental groups, these early submissions benefited from the support of some states, and from the apparent concern of arbitral tribunals to ensure that proceedings are perceived to be 'transparent' rather than 'secretive'. ${ }^{\text {5 }}$ 4

These actions appear to have played a pivotal role in promoting rules reform first in North America, and then globally. Under NAFTA, a 2003 statement of the NAFTA Free Trade Commission, issued after the first amicus curiae application and partly drawing on that experience, established a process for non-disputing party submissions. ${ }^{\mathrm{I} 55}$ This process was then applied to the arbitration where NGO action first raised the issue. ${ }^{156}$ Further, the US model investment treaty of 2004 and actual US treaties concluded from around that time introduced language allowing tribunals to accept amicus curiae submissions. ${ }^{157}$ Amendments in the ICSID Arbitration Rules followed in 2006, empowering ICSID arbitral tribunals to accept amicus curiae submissions. ${ }^{158}$ In 2013 and with input from non-governmental actors, ${ }^{159}$ UNCITRAL introduced new Rules on Transparency that also empower tribunals to accept amicus curiae submissions. ${ }^{160}$ A multilateral convention adopted in 2014 aims to facilitate the application of the new UNCITRAL Rules on Transparency to arbitrations based

I53 Aguas Argentinas, S.A., Suez, Sociedad General de Aguas de Barcelona, S.A. and Vivendi Universal, S.A. v. The Argentine Republic (Order in Response to A Petition for Transparency and Participation as Amicus Curiae, 2005) ICSID Case No. ARB/03/I9, available at www.italaw.com/sites/default/files/case-documents/itao8I5.pdf.

154 Methanex Corporation v. United States of America, supra note I52, at 49. In this arbitration, the respondent US government (Ibid., at I6-23) and Canada (Ibid., at Io) supported allowing the amicus curiae submissions, while Mexico (Ibid., at 9) and the claimant (Ibid., at I 2-I5) opposed them.

I55 'Statement of the Free Trade Commission on Non-Disputing Party Participation' (7 October 2003), available at www.state.gov/documents/organization/38791.pdf. On the relationship between the Methanex case and this statement, see H. Mann, 'The Free Trade Commission Statements of October 7, 2003, on NAFTA's Chapter I I: Never-Never Land or Real Progress?', (2003) International Institute for Sustainable Development Comment, available at www.iisd.org/pdf/2003/trade ftc comment octo3.pdf (Harrison, supra note I42, at 402).

${ }^{156}$ Methanex Corporation v. United States of America ${ }^{-}$(Amicus Curiae Submissions by the International Institute for Sustainable Development, 9 March 2004), UNCITRAL, NAFTA Ch. I I available at www.state.gov/documents/organization/30475.pdf; Methanex Corporation v. United States of America (Submission of Non-Disputing Parties Bluewater Network, Communities for a Better Environment and Center for International Environmental Law, 9 March 2004), UNCITRAL, NAFTA Ch. I I, available at www.state.gov/documents/organization/30472.pdf; Methanex Corporation v. United States of America (Letter from the Tribunal, 6 April 2004), UNCITRAL, NAFTA Ch. II, available at www.italaw.com/sites/default/files/case-documents/itao524.pdf.

157 US Model Investment Treaty of 2004, Art. 28(3), available at www.state.gov/documents/organization/I I 760 I. pdf; 2003 United States-Singapore Free Trade Agreement, 42 ILM Io26 (2003), Art. I5.I9(3). The US Model Investment Treaty of $20 \mathrm{I} 2$ takes a similar approach. US Model Investment Treaty of 20I 2, Art. 28(3), available at www.state.gov/documents/organization/I8837I.pdf.

I58 ICSID Rules of Procedure for Arbitration Proceedings (Arbitration Rules), Art. 37(2). On this amendment and the significance of earlier changes in US investment treaty practice, see A.R. Parra, The History of ICSID(20I2), 249-50.

I59 See, e.g., F. Marshall and H. Mann, 'Good Governance and the Rule of Law: Express Rules for Investor-State Arbitrations Required', (2006) International Institute for Sustainable Development Submissions, available at www.iisd.org/pdf/2006/investment_uncitral_rules_rrevision.pdf; 'Comments on Draft Rules on Transparency in Investor-State Arbitration', (20-̄i) Cénter for International Environmental Law and International Institute for Sustainable Development, available at www.iisd.org/ sites/default/files/publications/uncitral_comments_draft_rules.pdf.

I60 UNCITRAL Rules on Transparency in Treaty-based Investor-State Arbitration (30 July 20I3), Art. 4, available at www.uncitral.org/pdf/english/texts/arbitration/rules-on-transparency/pre-release-UNCITRAL-Rules-onTransparency.pdf. See L. Johnson and N. Bernasconi-Osterwalder, 'New UNCITRAL Arbitration Rules on Transparency: Application, Content and Next Steps', (2013) International Institute for Sustainable Development and Center for International Environmental Law, available at ccsi.columbia.edu/ files/20I4/04/UNCITRAL_Rules_on_Transparency_commentary_FINAL.pdf. 
on investment treaties concluded before 20I4. ${ }^{\mathrm{I}}{ }_{\mathrm{I}}$ Several investment treaties contain provisions on amicus curiae submissions, which would apply irrespective of the arbitration rules governing the arbitration. ${ }^{\mathrm{I} 62}$

Important restrictions remain, for example in relation to public access to hearings and case documentation, and to transparency in amicable settlements. ${ }^{\mathrm{I} 3}$ In practical terms, limited access to the necessary resources and expertise may also prove a barrier. In addition, arbitral tribunals enjoy considerable discretion in deciding whether to accept amicus curiae submissions, and what use, if any, to make of the arguments contained therein. Further, there is no systematic evidence of the difference, if any, that the submissions make to the outcomes of arbitration. Nonetheless, these legal developments constitute a significant change in the formal space for citizen engagement with investor-state arbitration. The reforms have paved the way to further NGO activity. Tribunals have accepted amicus curiae submissions in several investment disputes, including cases relating to water supply contracts, investor challenges to legislation designed to reverse historical injustices, and disputes stemming from extractive industry projects. ${ }^{164}$ Practitioner-based insights suggest that savvy collective action, not just legal expertise, has been an important factor in this growing citizen engagement with investor-state arbitration. In one arbitration concerning a mining project in El Salvador, for example, amicus curiae submissions were sustained by an alliance including grassroots groups based in the affected mining areas; national NGOs capable of turning local issues into national policy debates; and international NGOs with the legal expertise and campaigning clout to take the issue to a global level. ${ }^{\mathrm{I} 65}$

This brief discussion of amicus curiae submissions is not intended to provide an exhaustive analysis of the complex relationship between democratic governance and investor-state arbitration. However, the findings shed some light on the dynamic interlinkages that exist between the rules- and action-based dimensions of democratic governance. NGO action to assert public scrutiny over arbitration processes preceded and most likely promoted formal changes in applicable rules, which in turn paved the way to further citizen engagement in a range of arbitration contexts. This insight may stimulate reflection on tackling the gulf that exists between action-based initiatives to promote democratic oversight of investment treaty mak-

I6I 2014 Convention on Transparency in Treaty-Based Investor-State Arbitration, 54 ILM 747 (2015) (Mauritius Convention).

I62 See, e.g., 2006 Agreement Between the Government of Canada and the Republic of Peru for the Promotion and Reciprocal Protection of Investments, Canada Treaty Series 2007/ro (2007), Art. 39, available at www.treaty-accord.gc.ca/text-texte.aspx?id=105078\&lang=eng; and, in significantly more concise terms, 20I3 Agreement Between the Government of Canada and the Government of the Republic of Benin for the Promotion and Reciprocal Protection of Investments, Canada Treaty Series 20I4/I3 (20I4), Art. 34, available at www.international.gc.ca/trade-agreements-accords-commerciaux/agr-acc/fipa-apie/benin-text.aspx?lang= eng.

I63 E.M. Hafner-Burton and D.G. Victor, 'Secrecy in International Investment Arbitration: An Empirical Analysis', (20I6) 7(I) Journal of International Dispute Settlement I6I-82.

I64 For one example among many, see, e.g., Pac Rim Cayman LLC v. The Republic of El Salvador (Procedural Order No. 8, 20II) ICSID Case No. ARB/og/r2, available at www.italaw.com/sites/default/files/ case-documents/itao6 I 5.pdf.

I65 M. Orellana, S. Baños, and T. Berger, Bringing Community Perspectives to Investor-State Arbitration: The Pac Rim Case (2015), 7-8, available at pubs.iied.org/I2579IIED.html. 
ing on the one hand, and the often limited formal channels for influence on the other. For research agendas, the relevance of action-based dimensions highlights the importance of investigating not just the technical issues involved in the design and implementation of applicable rules (the traditional purview of legal analysis), but also the real-life conditions that can enable, or constrain, action to push the boundaries of applicable law.

\section{Conclusion}

Over the past decades, economic globalization has been accompanied by extensive developments in the international law governing foreign investment. Investor-state arbitration creates a unique space for international review of public action, and international investment law has come to intersect with a wider range of policy areas than was the case a few decades ago. These developments involve complex technical issues, but also political choices - not least because the international investment regime can affect the way the costs of public action are distributed between governments and businesses. While at least partly founding its legitimacy on the purported exclusion of foreign investors from the democratic process, the investment regime in fact raises probing questions about its relationship with democratic governance.

This article developed an analytical framework for exploring that relationship, mobilizing the notions of rules- and action-based democracy to examine three interlinked themes: how the investment regime intersects with democratic space at the national and subnational level; the place of democratic processes in the making of investment treaties; and public participation in investor-state arbitration. The findings point to a great diversity of contexts, to limitations in the legal rules enabling democratic oversight of investment treaty making, and to growing citizen engagement with the investment regime, particularly in medium- and high-income polities. There is a gulf between, on the one hand, the far-reaching developments in the international legal frameworks governing cross-border investment, which are prompting parliaments and citizens to seek a greater say in investment treaty policy; and on the other, the enduring limitations that, depending on context, may affect formal opportunities for democratic oversight of those frameworks. As a result, the response to what some perceive as a 'legitimacy crisis' of the international investment regime cannot be just a technical fix, a reflection on technical options for the recalibration of investment treaties. A full response arguably requires strengthening democratic oversight of the international investment regime.

The interplay between rules- and action-based dimensions of democracy is at the centre of these reflections. Historically, international investment law has emerged through a highly dynamic process involving decentralized negotiation and contestation. ${ }^{166}$ This feature is reflected in relations between states, which negotiate the treaties, and between law makers and those called upon to interpret and apply the law -for example, where states have refined treaty formulations in response to arbit-

I66 See also J. Pauwelyn, 'Regime Composition, Emergence, and Change', in Z. Douglas, J. Pauwelyn and J.E. Viñuales (eds.), Foundations of International Investment Law: Bringing Theory into Practice (2014), I I-43. 
ral interpretations. The dynamic, decentralized nature of international investment law is also reflected in the role of non-state actors: NGO action kick-started amicus curiae submissions in investor-state arbitration, with the subsequent legal reforms to formalize and regulate this practice in turn enabling greater citizen engagement with arbitration proceedings. In analytical terms, the dynamic nature of the international investment regime compounds the case for considering not just the rules, but also the action-based dimensions that underpin their evolution. And in policy terms, action-based developments affecting public and parliamentary scrutiny of international investment law call for reforming the rules to enhance and clarify formal opportunities for democratic oversight. While the past I 5 years have witnessed an opening up, albeit partial, of investor-state dispute settlement, time is now ripe to reconsider spaces for democratic decision-making in the development of investment law.

Against the backdrop of the often sweeping statements made about the erosion of state power in the context of economic globalization, states (and supranational polities such as the EU) remain important sites for democratic action. Two factors underpin this continued importance. First, states play a central role in shaping the legal regime for cross-border investment flows. States negotiate investment treaties, so it is states that have the legal authority to do and undo investment treaties, or recalibrate their content - even though their ability to influence negotiations varies significantly due to imbalances in negotiating power. ${ }^{167}$ Second, depending on political systems states may provide the primary spaces for democratic governance. For these reasons, much action to strengthen democratic oversight has targeted public authorities in relation to a polity's participation in international treaty making. Context does matter, however, particularly given the very diverse degrees of political space that exist in different polities - from democratic countries to authoritarian regimes.

The continued importance of national and supranational polities provides pointers for possible reforms. Specifics inevitably depend on the context. In the EU, for example, the Lisbon Treaty expanded the competences of the EU and enhanced the powers of the European Parliament. Key issues involve clarifying the competences of EU and national authorities in investment treaty policy, and strengthening the relationships of communication and accountability between citizens and members of the European Parliament. ${ }^{168}$ Globally, and depending on the context, reforms may involve rethinking constitutional rules and practices to increase transparency throughout treaty negotiations, and to empower parliament to play a greater role in providing guidance ahead of treaty negotiations, scrutinizing those negotiations and properly deliberating on ratification. Parliamentarians need specialized technical support if they are to play their role effectively in a policy arena involving complex technical issues. Besides strengthening the institutions of representative democracy, there is scope for imaginative thinking about workable legal arrangements to enable more direct forms of democratic governance, building on les-

167 Schneiderman, supra note 2, at 7.

I68 See also Kleimann and Kübek, supra note 132. 
sons from the advances and challenges involved in early experiences with citizens' initiatives and other bottom-up processes.

At the same time, the investment regime has created new spaces for citizen engagement at the international level. International investment law involves the delegation of authority to investor-state arbitral tribunals, and the growing body of amicus curiae submissions shows that these international processes provide some opportunities for citizen engagement. But it is the treaty making stage that presents greater scope for influencing the key parameters of the investment regime. Multiple polities are grappling with similar issues, creating considerable room for citizen action that transcends national boundaries. While investment treaty negotiations are bilateral or regional, there is scope for international spaces to facilitate public debate, lesson sharing, and alliance building - complementing existing expert- and government-led processes on the technical aspects of international investment law with more open spaces for citizens' groups and parliamentarians to reflect on the underlying policy choices. Such international initiatives may also catalyze public debate in low-income countries where citizen or parliamentary engagement has so far been more limited.

In the longer term, strengthening democratic oversight could help to both foster reconsideration of the parameters of international investment law and increase its perceived legitimacy. Promoting informed public debate in arenas dominated by complex technical issues and major economic stakes presents practical challenges. These challenges are likely to prove particularly difficult in low-income countries where capacity constraints may be more acute (as reflected, for example, in lower literacy rates) and political space for genuine dialogue more limited. At the same time, international investment law provides a test case for wider efforts to design systems of democracy that are able to deliver, at scale, bottom-up policy making in relation to politically and economically sensitive issues. At the very least, discussions about the investment regime can feed into wider debates about strengthening democratic oversight of international law making in more general terms. Seizing the opportunity requires imaginative ideas and practice, and sharing lessons from innovation. Amid narratives of 'post-truth' politics, ${ }^{169}$ it is clear that citizen engagement must build on rigorous analysis if it is to be properly informed. Therefore, there is a need for accessible but accurate information to enable citizens to make up their minds, and an important role for scholarship to generate evidence and inform public choices on the future of international investment law.

${ }^{169}$ 'Word of the Year 2016 Is...', English Oxford Living Dictionaries (2016), available at en.oxforddictionaries.com/word-of-the-year/word-of-the-year-20ı6. 